\title{
ARTICLES
}

\section{EXPECTING TOO MUCH AND TOO LITTLE OF LAWYERS ${ }^{\dagger}$}

\author{
Eugene R. Gaetke ${ }^{\dagger \dagger}$
}

Table of Contents

I. Introduction . . . . . . . . . . . . . . . . . . . . . . . . . . . . . . . . 694

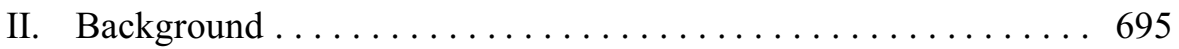

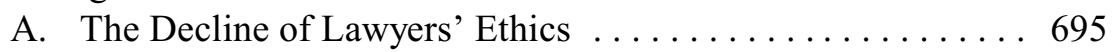

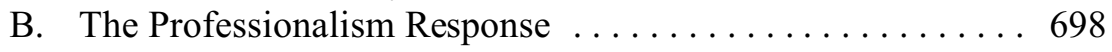

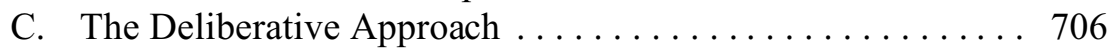

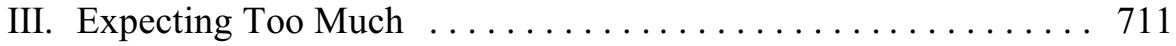

IV. Expecting Too Little . . . . . . . . . . . . . . . . . 722

V. Using Rules to Improve Lawyers' Professionalism . . . . . . . . . 729

A. The Prospect for Compliance . . . . . . . . . . . . . . 729

B. The Need for Enforcement . . . . . . . . . . . . . . . 735

C. The Broader Role of Rules .................. 738

D. A Place to Start ...................... 741

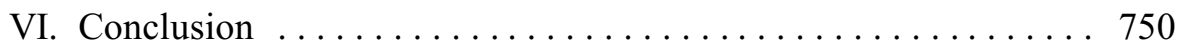

$\dagger \quad$ Copyright 2005 by Eugene R. Gaetke.

i† H. Wendell Cherry Professor of Law, University of Kentucky College of Law; B.A., J.D., University of Minnesota. The author would like to thank George D. McClure, Brittany Hayes Koenig, and Laura Tzanetos for their research assistance in the preparation of this article. 


\section{INTRODUCTION}

The regulation of lawyers' behavior remains a controversial topic. Over the past hundred years, the organized bar has engaged in a number of efforts to generate rules governing lawyers' conduct. Still, prominent lawyers and jurists, the public media, and legal scholars perceive an ongoing decline in the profession's ethics.

Bar leaders tend to respond to the problem by calling for greater "professionalism" among practicing lawyers. Drawing on professional images from earlier times, they urge lawyers to look beyond the rules and to be more virtuous, selfless, independent of clients, and dedicated to justice.

A number of commentators go further. These critics maintain that the profession's reliance on statute-like rules and codes deters broader ethical deliberation by lawyers and encourages the zealous pursuit of the narrow interests of clients, thus causing lawyers to act unethically and diminishing the collective professional image of the bar. To address this concern, some writers urge the bar to reduce its current dependence on legalistic rules and codes in addressing professional misconduct.

Neither the bar's focus on notions of professionalism nor the critics' proposed retreat from rules of legal ethics, however, offers much promise for improving the ethical behavior of lawyers. These approaches posit that lawyers will respond to moralistic appeals or react to the reduction or elimination of legalistic rules and codes by disregarding their legal duties to, and personal relationships with, their clients in order to behave more "ethically." In doing so, these approaches expect too much of lawyers. At the same time, they neglect or eschew entirely the use of sound rulemaking, the primary and perhaps only workable mechanism for defining and demanding a higher level of professional behavior from lawyers. Thus, the approaches expect too little of lawyers.

Rules play an important part in determining the profession's values and the level of ethics and professionalism within the bar. The primary problem with the present rules, however, is not the failure of lawyers to embrace voluntarily a higher sense of professionalism nor the rules' legalistic tone and mandatory effect. The present rules fail to fulfill their task because they fall short of setting standards of behavior for lawyers that are consistent with what the public should demand of the profession and what the profession should expect of itself. 


\section{BACKGROUND}

\section{A. The Decline of Lawyers' Ethics}

Critics of the legal profession often proclaim that lawyers are greedy, dishonest, and otherwise unprincipled, ${ }^{1}$ and opinion surveys show that the public largely agrees. ${ }^{2}$ Even disregarding such overly inclusive and often uninformed character attacks on an entire profession, there is reason for concern. Thoughtful commentators pointedly assert that lawyers tend to act unethically by pursuing their clients' objectives too single-mindedly without concern for the negative impact of these efforts on other interests, including those of adversaries, third persons, the judicial system, and society. ${ }^{3}$

1. John A. Humbach, The National Association of Honest Lawyers: An Essay on Honesty, "Lawyer Honesty" and Public Trust in the Legal System, 20 PaCe L. Rev. 93, 93-94 (1999) (critiquing lawyers' proclivity for dishonesty and positing that the public's low regard for lawyers is attributable to lawyers' belief that "the duty of loyalty to clients requires a lawyer to mislead," and arguing that the result of this belief is that "on the questions that ultimately matter, most lawyers do not even purport to present the objective truth" (emphasis omitted)).

2. A 2002 poll prepared for the American Bar Association (“ABA") Section of Litigation illustrates the point. Leo J. Shapiro \& Associates, Public Perceptions of Lawyers: Consumer Research FinDINGS 8, 18 (2002), available athttp://www.abanet.org/litigation/lawyers/publicperceptions.pdf(noting that consumers generally describe lawyers as "greedy, manipulative and corrupt" with 69 percent of respondents agreeing with the statement that "lawyers are more interested in making money than in serving their clients," and 73 percent agreeing that "lawyers spend too much time finding technicalities to get criminals released"). Other polls have led to similar conclusions. Marc Galanter, The Faces of Mistrust: The Image of Lawyers in Public Opinion, Jokes, and Political Discourse, 66 U. CIN. L. Rev. 805, 808-10 (1998) (discussing statistical data regarding public attitudes about lawyers and the lack of public trust in lawyers); Symposium, Improving the Professionalism of Lawyers: Can Commissions, Committees, and Centers Make a Difference?, 52 S.C. L. Rev. 443, 490 (2001) (noting that the public thinks that lawyers are "greedy ... dishonest, deceitful, manipulative, and uncaring" and citing a 1993 survey by Peter Hart for the ABA); Robert A. Clifford, Confronting our Critics, LiTIG., Winter 2002, at 1, 1 (citing research done by the ABA reporting that "Americans say that lawyers are greedy, manipulative, and corrupt"); Gary A. Hengstler, Vox Populi: The Public Perception of Lawyers: ABA Poll, A.B.A. J., Sept. 1993, at 60, 62-63 (reporting the results of an ABA opinion poll regarding the public's perception of lawyers and noting that only 22 percent of respondents believe that the phrase "honest and ethical" provides an accurate description of lawyers, and 59 percent believe lawyers are "greedy"). Most recently, a December 2004 Gallup poll on the public's rating of the honesty and ethical standards of various "professions" placed lawyers 19th out of 21, ahead of only "advertising practitioners" and "car salesmen." David W. Moore, Nurses Top List in Honesty and Ethics Poll, Gallup Poll News Serv., Dec. 7, 2004, http://www.poll .gallup.com/contentdefault.aspx?cI=14236.

3. See, e.g., Trina Jones, Inadvertent Disclosure of Privileged Information and the Law of Mistake: Using Substantive Legal Principles to Guide Ethical Decision Making, 48 EMOR Y L.J. 1255, 1260 (1999) ("Given the extremely adversarial nature of contemporary legal practice, too often lawyers appear not as deliberative decision makers, carefully balancing the consequences of their actions, but rather as knee-jerk reactionaries willing to do whatever it takes to advance their client's cause regardless of the costs involved. This apparent abandonment of judgment leads the public to conclude that many lawyers have little or no 
Although public dissatisfaction with the legal profession is apparent, whether lawyers' ethical conduct is truly in decline is an open question. At one extreme, some assert not only that there is such a decline but that it has reached crisis proportions. ${ }^{4}$ Some of these observers point to economic pressures $^{5}$ and legal changes ${ }^{6}$ during the last two decades of the twentieth century that are said to have converted the legal profession into a mere business, and not an attractive one at that, ${ }^{7}$ and have raised the level of

concern about legal merit or justice.”).

Professor David Luban observes: "The commonest and bitterest complaint against the legal profession is that lawyers do not give a damn about justice, or, when they do, it is despite their profession rather than because of it. This means that the law has to do with justice only accidentally." DAVID LuBAN, LAWYERS and Justice: An Ethical Study xvii (1988). This contention can be framed as a critique of lawyers' dependence on role-differentiated morality: the notion that lawyers' professional role in the legal system excuses the commission of otherwise immoral acts on behalf of their clients. Id. at 52-53. For example, lawyers might use this defense as their justification for impeaching a truthful witness, for keeping secret a client's admission regarding the commission of a crime or the location of damaging evidence, or for using to a client's advantage information mistakenly provided by an opponent. Id. at 53-54.

4. See, e.g., Susan Daicoff, Lawyer, Know Thyself: A Review of Empirical Research on Attorney Attributes Bearing on Professionalism, 46 AM. U. L. REv. 1337, 1340 (1997) (“[T]hree related crises have emerged with respect to the legal profession: 'professionalism' has declined, public opinion of attorneys and the legal profession has plummeted, and lawyer dissatisfaction and dysfunction have increased."); Jones, supra note 3, at 1257 ("The decline of professionalism, especially in the law, has taken on epidemic proportions." (citing Warren E. Burger, Remarks, The Decline of Professionalism, 63 FordHAm L. Rev. 949 (1995))). Evidence regarding the existence of such a crisis, however, is primarily anecdotal. Peter A. Joy, What We Talk About When We Talk About Professionalism, 7 Geo. J. Legal Ethics 987, 989 (1994) (reviewing Lawyers' Ideals/Lawyers' Practices: Transformations in the American Legal Profession (Robert L. Nelson et al. eds., 1992) [hereinafter Lawyers' Ideals/Lawyers' Practices]). Offering historical perspective, Rayman L. Solomon observes that concern about the professionalism of lawyers was fairly constant during the years 1925-60, although five periods within that time could be characterized as crises. Rayman L. Solomon, Five Crises or One: The Concept of Legal Professionalism, 1925-1960, in LaWyers' Ideals/Lawyers' Practices, supra, at 144, 145.

5. Evidence of these pressures includes the recent mergers and dissolutions of large law firms. Daicoff, supra note 4, at 1344-45. Professor Solomon concludes that, unlike the four earlier professionalism crises during the 1925-60 period he studied, the current crisis of professionalism at the end of the 20th Century arises from concerns regarding the commercialization of the practice of law, which may result from "the current dramatic changes in the economic structure of the practice of law." Solomon, supra note 4 , at 173 .

6. For example, Chief Justice Warren Burger was noteworthy in his criticism of contemporary lawyers for succumbing to the attraction of professional advertising after the Supreme Court's decision in Bates v. State Bar of Arizona, 433 U.S. 350 (1977). Warren E. Burger, The Decline of Professionalism, 61 Tenn. L. Rev. 1, 5-7 (1993). Other legal trends such as the approval of some forms of solicitation, see Model Rules of Prof'L Conduct R. 7.3 (2003), and fee-splitting among lawyers not in the same firm, see id. R. 1.5(e), have eroded the line between the practice of law and other forms of business.

7. For a representative listing of a sample of sources so asserting, see Daicoff, supra note 4, at 1344 n.17. See also Samuel J. Levine, Faith in Legal Professionalism: Believers and Heretics, 61 MD. L. Rev. 217, 218-19 (2002); The Second Driker Forum for Excellence in the Law, 42 WAYNE L. REV. 115, 121-22 (1995) (remarks of Anthony T. Kronman) ("The bottom line has become the only line for ... [America's 
competitive behavior among the burgeoning body of lawyers. At the other extreme are commentators who dispute the very existence of the trend, ${ }^{8}$ with some recognizing that the American legal profession has always been subject to such criticisms ${ }^{9}$ and others noting that those perceiving a decline may merely be nostalgic for a golden era in the profession that never really existed. ${ }^{10}$

For purposes of this discussion, however, no attempt will be made to join, let alone resolve, this debate. It is apparent that there is widespread dissatisfaction with the behavior of lawyers among those within the profession and those outside it. Because the public's faith in lawyers is considered important to its confidence in the legal system,${ }^{11}$ the perception of declining

large law firms].”).

8. Milton V. Freeman, Remarks, The Profession of Law is NOT on the Decline, 96 Dick. L. REv. 149, 162-63 (1992); Michael J. Rooney, Report on Professionalism; The ABA Attempts Suicide, 75 ILL. B.J. 480, 480 (1987) ("I, for one, simply do not believe there has been a decline in professionalism among lawyers."); John H. Pickering, My Personal Verdict, After 55 Years: The Profession's Better Than Ever, EXPERIENCE, Summer 1995, at 22, 23 ("I do not share the gloom and doom that there has been a decline in professionalism.").

9. Judith S. Kaye, Women Lawyers in Big Firms: A Study in Progress Toward Gender Equality, 57 Fordham L. ReV. 111, 115 (1988) (observing that "law is inherently not a popular profession" and "in every age the profession has been criticized as too much a business"); Colin Croft, Note, Reconceptualizing American Legal Professionalism: A Proposal for Deliberative Moral Community, 67 N.Y.U. L. Rev. 1256, 1258-59 (1992) ("Acknowledging the historical prevalence and persistence of such unfavorable sentiments, however, calls into question the recurrent claim that legal professional standards have declined in recent decades. If standards were indeed higher in days past, one would expect this to have been reflected in greater public esteem for the legal profession at that time, which the historical record does not support.”).

10. Richard L. Abel, Theories of the Legal Profession, in LAwYERs: ACRITICAL READER 117, 131 (Richard L. Abel ed., 1997); Marc Galanter, Lawyers in the Mist: The Golden Age of Legal Nostalgia, 100 Dick. L. Rev. 549 (1996); W. Bradley Wendel, Morality, Motivation, and the Professionalism Movement, 52 S.C. L. Rev. 557, 566-67 (2001); see also Symposium, Teaching and Learning Professionalism, 1996 A.B.A. Sec. on Legal Educ. And Admission to the B. Rep. 4-5 [hereinafter 1996 ABA Symposium Proceedings]; Russell G. Pearce, The Professional Paradigm Shift: Why Discarding Professional Ideology Will Improve the Conduct and Reputation of the Bar, 70 N.Y.U. L. Rev. 1229, 1231-32 (1995).

11. Humbach, supra note 1, at 93 ("Distrust of lawyers is not . . . just an image problem of an insular profession. Our basic civic order relies on the legal system and public respect for it. If the public cannot trust the lawyers who are entrusted with the legal system, there is a problem that casts a shadow on the integrity of the very concept of rule of law.").

The ABA promotes the link between lawyers' status and the quality of the judicial system. In the Preamble to its 2003 Model Rules of Professional Conduct, the ABA emphasizes the public nature of the lawyer's role. It declares that "[a] lawyer, as a member of the legal profession, is a representative of clients, an officer of the legal system and a public citizen having special responsibility for the quality of justice." Model Rules of Prof'L Conduct Preamble (2003). The ABA also declares that "a lawyer should further the public's understanding of and confidence in the rule of law and the justice system because legal institutions in a constitutional democracy depend on popular participation and support to maintain their authority." Id. Finally, the ABA notes the importance of maintaining public trust in the legal profession's 
behavior among lawyers could be said to be as important as the reality. The commonly expressed, negative attitudes about lawyers implicitly suggest that the system regulating lawyers' conduct is failing and that the current rules governing lawyers' behavior are not achieving their intended purpose. The question, therefore, is what can be done to improve lawyers' conduct and, thereby, public attitudes regarding it.

\section{B. The Professionalism Response}

The public's attitudes about lawyers are reflected in common assertions, particularly from within the bar itself, ${ }^{12}$ that modern lawyers' "professionalism" is in decline. ${ }^{13}$ Viewed in these terms, the solution to the problem of worsening behavior among lawyers is to reinvigorate professionalism as a value among lawyers.

continued self-governance, stating:

To the extent that lawyers meet the obligations of their professional calling, the occasion for government regulation is obviated. Self-regulation also helps maintain the legal profession's independence from government domination. An independent legal profession is an important force in preserving government under law, for abuse of legal authority is more readily challenged by a profession whose members are not dependent on government for the right to practice.

Id. Indeed, it has been asserted that, because of lawyers' predominance in all branches of governmental service, professionalism concerns about lawyers affect public confidence in all three branches of government, not just the judiciary. Daicoff, supra note 4, at 1347-48.

Not all agree that the public's apparent distrust of lawyers correlates with a lack of confidence in the judicial system. For an interesting discussion of this relationship and a challenge to the common assumption, see Andrew M. Perlman, Toward a Unified Theory of Professional Regulation, 55 FLA. L. REV. 977, 1010-15 (2003).

12. A list of citations to a sample of such commentary is offered in Daicoff, supra note 4, at 1344 n.15. Susan Daicoff's electronic research in August 1997 revealed 145 articles in legal periodicals with "professionalism" in their titles. Id. at 1347 n. 33. As noted by Professor Samuel Levine, three prominent books by legal luminaries have been regarded as leading commentaries on the decline of lawyers' professionalism: Mary Ann Glendon, A Nation Under Lawyers: How the Crisis in the Legal Profession Is Transforming American Society (1994); Anthony T. Kronman, The Lost Lawyer: Failing Ideals of the Legal Profession (1993); and Sol M. Linowitz with Martin Mayer, The Betrayed Profession: Lawyering at the End of the Twentieth Century (1994). Levine, supra note 7, at $222 \& \mathrm{n} .21$. An interesting discussion and critique of the professionalism movement is provided by Rob Atkinson, A Dissenter 's Commentary on the Professionalism Crusade, 74 Tex. L. Rev. 259 (1995).

13. See, e.g., Burger, supra note 6, at 2-3 (describing the "decline of professionalism," the author notes that "the standing of our profession is at its lowest ebb since [he] came to the bar sixty-two years ago"). 
Despite its appealing tone,${ }^{14}$ there is no agreed meaning for the term "professionalism."15 In its narrowest usage, the term can serve synonymously for such virtues as honesty and competence, ${ }^{16}$ qualities generally recognized as important to all professions. Used in this sense, "professionalism" is merely a redundant reference to broad, existing legal standards applicable to the legal profession. ${ }^{17}$ Perhaps in its broadest usage, popular among law school orientation ${ }^{18}$ and commencement speakers, "professionalism" encompasses vague references to higher levels of morality and ethics ${ }^{19}$ and is frequently tied to the notion that being a lawyer should be a "calling" rather than a mere vocation, ${ }^{20}$ adding a further level of vagueness to the concept.

14. "Professionalism" undoubtedly purports to convey what is good about the legal profession. Roger C. Cramton, On Giving Meaning to "Professionalism," in 1996 ABA Symposium Proceedings, supra note 10, at 8 ("[E]veryone talks about professionalism as an icon or goal of lawyering."); MICHAEL J. Kelly, Lives of Lawyers: Journeys in the Organizations of Practice 14 (1994) ("Practicing lawyers are never opposed to professionalism. Professionalism is the law's apple pie and motherhood.").

15. Levine, supra note 7, at $221 \mathrm{n}$. 19. In observing the lack of meaning for the term, Dean Michael J. Kelly maintains that "[ $t]$ he meaning of professional values is now so malleable that the terms professional and professionalism are now well-nigh useless." Kelly, supra note 14, at 13. He further notes:

The words have an almost incantatory function, combined with the special utility of so many meanings that listeners or readers can take what they want from them, ranging roughly from concepts of business acumen to high moral principle to proficiency and lofty standards of quality. And they have one other quality that is invaluable: favorable resonance. In whatever mode of meaning, they generate agreeable vibrations or responses from the reader or listener. Id. at 9 .

16. For further discussion of professionalism efforts that so view the concept, see infra text accompanying note 39 .

17. Honesty and competence are the subjects of specific Model Rules governing lawyers' behavior. For example, Model Rules 3.3(a)(1), 4.1, and 8.4(c) pertain to honesty and Model Rule 1.1 to competence. Model Rules of Prof'L Conduct (2003).

18. Center on Professionalism at the University of South Carolina School of Law, Professionalism Primer and Problem-Solving Guide: AResource for Law Students (Roy Stuckey et al. eds., 2003) [hereinafter Professionalism Primer] (a pamphlet directed at incoming law students at that institution and focused on professionalism).

19. In the pamphlet distributed at the University of South Carolina School of Law, for example, a "Proposed Student Statement of Standards of Professional Conduct" is presented. Id. at 27. Among the exhortations to the students contained there are the following:

2. Principle: A law student should support a collegial atmosphere within the law school, embracing a culture of honesty, respect, and consideration.

...

4. Principle: A law student at all times should be guided by a fundamental sense of honor, integrity, and fair play.

$I d$. at 28. Interestingly, interspersed among the "descriptions" of the various general principles are included specific and less lofty admonitions that the law student should "actively participate in class but should not dominate the discussions[,] . . arrive on time for class and come prepared [, and ] . . regularly check his/her school mailbox and school e-mail account for important administrative notices." Id. at 28-29.

20. Kelly, supra note 14, at 14-15; Anthony T. Kronman, Foreword: Chapman University School 
In a particularly helpful discussion of the term, Professor Roger Cramton has identified the range of ways in which "professionalism" is used in discourse about lawyers. ${ }^{21}$ In this effort, he labels some of these usages of the concept as being "false faces of professionalism." 22 He points out that the term "professionalism" often is used in reference to allegations of declining civility among lawyers. ${ }^{23}$ Professor Cramton also notes that the term has been utilized to condemn excessive commercialism in the profession, especially as manifested in modern business-getting practices such as lawyer advertising and solicitation. ${ }^{24}$ He further notes that some commentators see professionalism as coextensive with the bar's struggle to meet its purported obligation to provide pro bono legal services to those needing them. ${ }^{25}$ Professor Cramton also observes that "professionalism" is used by some as the basis for their plea for continued self-regulation of the bar. ${ }^{26}$ In Professor Cramton's opinion, these four characterizations are too narrow in their focus and "masquerade as the real thing by treating a modest concern as the heart of the subject." 27

It would seem that most thoughtful commentators, however, have something more fundamental in mind when they lament the current decline of "professionalism" within the bar, framing their concern in terms of an expectation that lawyers curb their zeal on behalf of clients in favor of some broader societal good. Professor Cramton himself so concludes, relating "professionalism" to what he believes to be the "central moral tradition" of

of Law Groundbreaking Ceremony, 1 CHAP. L. Rev. 1, 3 (1998); Levine, supra note 7, at 218. Roscoe Pound is often quoted for his characterization of a "profession" as a group of persons "pursuing a learned art as a common calling in the spirit of a public service." Roscoe Pound, THe LAWYer From ANTIQUity to Modern Times 5 (1953) (emphasis added). The concept of a "calling" is reflected in the University of South Carolina School of Law's professionalism pamphlet's proposed student standards:

9. Principle: A law student should revere the law, the judicial system and the legal profession. Professionalism Primer, supra note 18, at 29 (emphasis added).

21. Cramton, supra note 14.

22. Id. at $14-17$.

23. Id. at 14. However, in Professor Cramton's view, civility is only a minor component of professionalism rather than a synonym for it. $I d$. He notes that "[c]ivility . . is not the core of the enterprise. It is like an elegant dessert, which dresses up and completes a good meal." Id.

24. Id. at 15. Professor Cramton finds this characterization of professionalism to be unsatisfactory because the practice of law in this country has always been a commercial enterprise, thus suggesting that commercialism should not be viewed as antithetical to the concept of professionalism. Id. at 15-16.

25. Id. at $16-17$.

26. Id. at 17 .

27. Id. at 14 . 
lawyering. ${ }^{28}$ Drawing on the work of Professor Robert Lawry, ${ }^{29}$ he sees "professionalism" in its true sense as embracing the idea that "the lawyer's primary obligation [is] to the procedures and institutions of the law" rather than to the interests of the client. ${ }^{30}$ Other prominent writers echo this characterization of the concept of the proper role of the lawyer. ${ }^{31}$ Though certainly not beyond debate, ${ }^{32}$ Professor Cramton's contention that the concept of professionalism means that lawyers owe their primary duty to the procedures and institutions of the law offers the most useful characterization of this frequently used term if it is to have any independent significance as a meaningful concept.

While defining the term is difficult enough, those urging greater professionalism among lawyers confront an even greater challenge when they attempt to suggest ways to accomplish this objective. Their proposals typically consist of various forms of appeals to lawyers' consciences. This approach is commonly reflected in professionalism initiatives, which seek only voluntary compliance, expressly eschew their use as legal standards, and

28. Id. at 7-8.

29. Robert P. Lawry, The Central Moral Tradition of Lawyering, 19 Hofstra L. ReV. 311 (1990). Professor Lawry notes, "If the primary duty of the lawyer is to the processes, procedures and institutions of the law, then the lawyer is the client's 'champion' only within that realm and only in ways the laws, social mores, and moral traditions of lawyering within that realm allow." Id. at 320-21.

30. Cramton, supra note 14 , at 8 .

31. Two notable examples are KRONMAN, supra note 12, at 18, and GLENDON, supra note 12, at 35-39.

32. The contention that lawyers' primary duty is to the procedures and institutions of the law rather than their clients' interests is at the center of the debates on a range of troubling issues in legal ethics. Some would say that the contention goes too far in subordinating the lawyer's duty to the client. For example, dramatic issues discussed by Professor Monroe H. Freedman result from the collision of the lawyer's duty to the client and the lawyer's duty to the law, the court, and the truth-seeking function of the judicial process. Monroe H. Freedman, Professional Responsibility of the Criminal Defense Lawyer: The Three Hardest Questions, 64 Mich. L. REV. 1469 (1966). Professor Freedman's conclusions on those issues indicate that he would not agree that the lawyer's primary obligation is to the procedures and institutions of the law rather than the client, at least in the criminal defense context. See id. at 1474-82. As further evidence of this debate, it also has been asserted that, if it ever prevailed, Professor Cramton's view of professionalism would ultimately fail anyway because it has been replaced by a business model that values primarily the pursuit of profit. Pearce, supra note 10, at 1264.

On the other hand, Professor Cramton's preferred characterization of professionalism is also subject to criticism for not going far enough in dulling the zeal of the lawyer in pursuing the client's objectives. For example, it has been argued that lawyers have a duty to work affirmatively toward a just result despite the effect of that effort on the clients' interests. William H. Simon, Ethical Discretion in Lawyering, 101 HARv. L. REv. 1083, 1090 (1988). Professor Simon excludes criminal matters from his argument. Id. at 1084. By urging lawyers to take direct responsibility for the substantive outcome of a matter it appears that Professor Simon has a more expansive view of the lawyer's duty of professionalism than Professor Cramton. Cf. id. at 1098. 
declare themselves to be subordinate to the mandatory disciplinary rules governing lawyer conduct.

In 1988, for example, the American Bar Association's House of Delegates urged state and local bar associations to "encourage their members to accept as a guide for their individual conduct, and to comply with, a lawyers' creed of professionalism. ${ }^{, 33}$ Various responsive efforts to draft such creeds ${ }^{34}$ note that they are not intended to "alter existing standards of conduct against which lawyer negligence might be judged or become a basis for the imposition of civil liability of any kind" 35 nor are they to "be deemed to supersede or in any way amend the Model Rules of Professional Conduct or other disciplinary codes." ${ }^{\prime 36}$ Other groups' efforts at drafting such codes, including those targeting civility among the members of the profession, display similarly precatory $^{37}$ and even apologetic overtones. ${ }^{38}$

In terms of substantive content, several other characteristics of these professionalism codes also may be noted. First, they typically contain numerous provisions encouraging conduct already demanded by the existing disciplinary rules. ${ }^{39}$ While there is nothing wrong with urging lawyers to do

33. A description of the ABA House of Delegates' August 1988 action is found at ABA/BNALAW. Manual on Prof. Conduct: Model Rules and Standards 1:401 (2004) [hereinafter Creed of Professionalism].

34. The ABA's Torts and Insurance Practice Section, for example, prepared a Lawyer's Creed of Professionalism. Id.

35. $I d$.

36. $I d$.

37. For example, the Civility Code employed in the Seventh Circuit notes in its Preamble that the standards contained there "are designed to encourage us, judges and lawyers, to meet our obligations to each other, to litigants and to the system of justice, and thereby achieve the twin goals of civility and professionalism." Final Report of the Committee on Civility of the Seventh Judicial Circuit, 143 F.R.D. 441, 448 (1992). The Preamble also expresses that the judges of the Seventh Circuit "expect judges and lawyers will make a mutual and firm commitment to these standards." Id. Finally, it notes that the "standards shall not be used as a basis for litigation or for sanctions or penalties" and that "[n]othing in these standards supersedes or detracts from existing disciplinary codes or alters existing standards of conduct against which lawyer negligence may be determined." Id.

38. One local bar association's efforts at compiling what might be characterized as a civility code notes that the "guidelines should not be construed as being a criticism of the Bar in general, or of any lawyers in particular, but merely as suggestions to all members of the Bar who are perhaps not aware of these matters." The Northampton County Bar Association Guide to Conduct and Etiquette at the Bar, reprinted in Thomas D. Morgan \& Ronald D. Rotunda, 2003 Selected Standardson Professional RESPONSIBILITY 699, at 702.

39. For example, the "Creed of Professionalism" adopted by the ABA's Torts and Insurance Practice Section includes provisions such as these:

A. With respect to my client:

....

4. I will advise my client against pursuing litigation (or any other course of action) that is without 
what the law already requires of them, such provisions tend to diminish the codes as devices for taking lawyers to new heights of ethical conduct. Second, when the codes do attempt to raise the bar of professional behavior, they often employ watered-down language, seemingly chosen to urge lawyers' mere consideration of the action rather than to encourage the action itself. ${ }^{40}$ This may be a step in the right direction, but, when viewed as components of a "creed," these provisions are overly tepid. Third, and perhaps most important, as these codes move into the areas of greatest importance to lawyers' professionalism, as that concept is defined by Professor Cramton, ${ }^{41}$ their provisions tend to declare the importance of certain professional values without express recognition of the potential for conflict with other compelling professional values and certainly without guidance as to how to resolve those conflicts. ${ }^{42}$ Most notably, in embracing the importance of the public good as

\section{merit;}

$\cdots$

B. With respect to opposing parties and their counsel:

....

2. I will not knowingly make statements of fact or of law that are untrue;

....

C. With respect to the courts and other tribunals:

...

11. I will at all times be candid with the court;

D. With respect to the public and to our system of justice:

....

2. I will endeavor to keep myself current in the areas in which I practice and, when necessary, will associate with, or refer my client to, counsel knowledgeable in another field of practice ....

Creed of Professionalism, supra note 33. All of these actions, encouraged by the "Creed of Professionalism," are currently mandated by the ABA's Model Rules of Professional Conduct. See ModEL Rules of Prof'l Conduct R. 3.1 (2003) (maintaining frivolous action or defense); Model Rules of PRof'L CONDUCT R. 4.1 (2003) (false statements of material fact or law to third persons); MODEL RULES of Prof'L Conduct R. 3.3 (2003) (false statements of fact or law to a tribunal); Model RULES OF Prof'L CONDUCT R. 1.1 (2003) (providing competent representation to a client).

40. For example, the ABA's Torts and Insurance Practice Section's "Creed of Professionalism" states that " $[\mathrm{w}]$ ith respect to the public and to our system of justice . . I will be mindful of the fact that, as a member of a self-regulating profession, it is encumbent on me to report violations by fellow lawyers of any disciplinary rule." CReEd of ProfessionAlism, supra note 33 (emphasis added). For example, rather than utilize language, providing that "I will report violations by fellow lawyers of any disciplinary rule," the "I will be mindful" language may have been necessary to secure endorsement of the creed by the adopting body. Perhaps the language utilized recognizes that other considerations, such as the severity of the violation or the client's legitimate interests, may be appropriate to weigh in deciding whether to report. However, as the "Creed of Professionalism" reads, it offers only the most limited encouragement to lawyers to report other lawyers' violations.

41. This occurs when they emphasize that lawyers' primary obligation is to the procedures and institutions of the law rather than to the interests of clients. See supra text accompanying notes 28-32.

42. As an example, the ABA's Torts and Insurance Practice Section's "Creed of Professionalism" 
an objective, the professionalism codes never clearly declare that the duty of zealous advocacy on behalf of the client's interests is to yield. ${ }^{43}$

Therefore, in terms of substance, professionalism codes do not offer much hope for elevating the conduct of lawyers. ${ }^{44}$ These codes urge voluntary adherence to standards already required of lawyers, ask only that lawyers consider or be mindful of certain professional concerns in representing their clients, and seek recognition of the importance of certain values removed from the context of conflicting professional values and the legal standards that incorporate them. ${ }^{45}$

In addition to such creeds and codes, those who promote the professionalism response to lawyers' unethical conduct often rely on educational efforts to instill better values in members of the profession. A number of proposals have been adopted for professionalism programs within

provides that

[w]ith respect to the courts and other tribunals ... I will be a vigorous and zealous advocate on behalf of my client, while recognizing, as an officer of the court, that excessive zeal may be detrimental to my client's interests as well as to the proper functioning of our system of justice. CREed of Professionalism, supra note 33. In encouraging lawyers to recognize the problems resulting from too much zeal, this provision offers even the most enthusiastic professionalism adherents little guidance as to what is "excessive zeal" and when it becomes "detrimental." Similarly, the same creed provides that "[w]ith respect to the public and to our system of justice ... I will remember that, in addition to commitment to my client's cause, my responsibilities as a lawyer include a devotion to the public good." Id. Just when the lawyer's commitment to the client is to yield to the public good is the difficult issue, however, and one not addressed by the creed.

43. Some authors recognize such conflicts but offer resolutions that are at best uncertain. For example, one work notes that civility is "among our basic professional values." Timothy P. Terrell \& James H. Wildman, Rethinking Professionalism, in Professionalism Primer, supra note 18, at 24. Even so, the authors suggest that civility is not an end in itself and that it "must be understood in its relation to several other principles, including quite fundamentally the lawyer's responsibility to his or her clients and their rights." $I d$. at 25 . The authors note that " $[\mathrm{t}]$ he limits imposed by civility will always therefore be vague and somewhat controversial, but they will also always remain relevant to professionalism." Id. While inconclusive on the point, the authors' position may be that civility is an important professional value but one that is subordinate to the professional value of zealous representation of the client.

44. This seems especially true for civility codes. Though seeing the development of civility codes as an "extraordinary movement," Professor Lawry criticizes these codes as viewing civility as an end in itself. Lawry, supra note 29, at 322. Professor Cramton seems to agree. Cramton, supra note 14, at 14. Professor Lawry notes that such codes should emphasize not only civility, but also "the way in which sharp and abusive practices [of lawyers] corrode the institutions and procedures of the law itself. That is the central point." Lawry, supra note 29 , at 322.

45. The same comments can be offered as to other limited approaches to specific issues of professionalism, in addition to those that address only civility among lawyers, such as those targeting professional problems involved in advertising and solicitation. See, e.g., Center for Professional Responsibility, American Bar Association, ABA Aspirational Goals on Lawyer Advertising (1988), available at http://www.abanet.org/cpr/professionalism/abaaspirationalgoals.html. 
law schools in an effort to reach those aspiring to enter the profession ${ }^{46}$ or have targeted new lawyers as they are admitted to the bar. ${ }^{47}$ Some states have added professionalism requirements to mandatory continuing legal education standards applicable to all lawyers. ${ }^{48}$ All of these programs are premised on the idea that such educational efforts will inculcate professional values and elevate the conduct of the educated lawyers. The general content of these programs is essentially the same as the substantive content of the professionalism creeds and codes ${ }^{49}$ and thus the educational component of the professionalism response suffers from the same shortcomings.

The goal of the professionalism response to the perceived decline in lawyers' ethical conduct is a noble one. In short, in addition to its reliance on voluntary cooperation, this effort tends to be characterized currently by the timid nature of its substantive content. We will return to an assessment of the

46. Atkinson, supra note 12, at 335 ("A recurrent theme in the professionalism crusade is the need for law schools to inculcate the virtues of professionalism."). In a foreword to the University of South Carolina School of Law's Professionalism Primer, supra note 18, Professor Roy Stuckey, the Director of the school's Center on Professionalism, states that "the Center helps introduce students to the traditions and values of the legal profession, and it supports the Law School's efforts to instill in students a commitment to the highest standards of the legal profession." Id. at 4. The bar in some states has provided similar orientation sessions for incoming law students. See, e.g., Sally Evans Lockwood, Orientations on Professionalism, 30 Ga. State B. J. 195 (1994) (describing programs offered in four Georgia law schools). At the University of Louisville's Brandeis School of Law, a professionalism program focuses on 30 hours of mandatory pro bono work as a requirement for graduation. See http://www.louisville.edu/brandeislaw/ academics/requirements.htm\#psp.

47. In Kentucky, a rule of the state supreme court requires each person admitted to the bar to complete a "New Lawyer Skills Program" within twelve months of admission. Ky. Sup. Cт. R. 3.652 (2005). The course is to be a minimum of 12.5 hours, $i d$. R. 3.652(1), and is to cover ethics, among other subjects. Failure to complete the course can result in suspension from the practice of law. Id. R. 3.652(9). This program, conducted by the state bar's Young Lawyers Section and Continuing Legal Education Commission, has focused on the role of the lawyer as an "officer of the court." KENTUCKY BAR Association, New Lawyer's Program: Practical information and Professional Values for KentuCKy's New Practitioners 3, 5-10 (2000).

48. In Ohio, for example, at least 2.5 hours of a lawyer's twenty-four hours of continuing legal education instruction must "be related to professional conduct" and include one hour of "instruction related to professionalism." Оhiо Gov. BAR R. X Section 3 (2006). Illinois lawyers must report at least four hours of continuing legal education in each two-year period "in the area of professionalism, diversity issues, mental illness and addiction issues, civility, or legal ethics.” ILL. Sup. Cт. R. 794(d) (2005).

49. For example, in its "Proposed Student Statement of Standards of Professional Conduct," the University of South Carolina's PROFESSIONALISM PRIMER, supra note 18, reflects the same approach as the organized bar's approach to professionalism concerns. It is voluntary in tone (declaring what students "should" do to act professionally), $i d$. at 27-29, although stating that students "must obey the law," $i d$. at 27. The standards to be pursued include competence and honesty, $i d$. at 28 , which are legal obligations already demanded of lawyers. The standards also urge students to "consider" taking action in some circumstances. Id. at 29 . 
prospects for improving the conduct of lawyers through this response in Part III.

\section{The Deliberative Approach}

One might naturally presume that if lawyers' conduct is disappointing, the fault lies with professional rules that are too lenient. Equally likely would be to conclude that the remedy for the perceived decline in lawyers' ethics would involve making the rules stricter and more legalistic in tone. Indeed, it can be seen that this has been the organized bar's approach to the subject of legal ethics over the past century. ${ }^{50}$ This is reflected in the ABA's adoption and abandonment of its 1908 Canons of Professional Ethics ${ }^{51}$ in favor of the 1969 Model Code of Professional Responsibility ${ }^{52}$ and its later adoption of the 1983 Model Rules of Professional Conduct, ${ }^{53}$ all evidencing a steady shift from aspirational professional norms to increasingly legalistic rules in the field of legal ethics. ${ }^{54}$

50. Charles W. Wolfram, Toward a History of the Legalization of American Legal Ethics-II The Modern Era, 15 Geo. J. Legal Ethics 205, 206-07 (2002) [hereinafter Wolfram, Legalization of Legal Ethics II]. Indeed, Professor Wolfram believes that most of that legalization has occurred since the 1970s. Id. at 222 .

51. Rather than being regulatory in nature, the 1908 Canons have been described as "a statement of professional solidarity - an assertion by elite lawyers in the ABA of the legitimacy of their claim to professional stature," Charles W. Wolfram, Modern Legal Ethics 54 (1986) (footnote omitted), and as "exaggerated exhortations arranged in a helter-skelter fashion," John F. Sutton, Jr., Re-Evaluation of the Canons of Professional Ethics: A Reviser's Viewpoint, 33 Tenn. L. Rev. 132, 138 (1966).

52. By adopting the Code, the ABA attempted to address the regulatory shortcomings of the 1908 Canons. This was done by making three categories of statements in the Code. The "Canons" were intended to be "axiomatic norms" stating "the general concepts" from which the rest of the Code statements were derived. Model Code of Prof'l Responsibility Preamble and Preliminary Statement (1980). The "Ethical Considerations" were "aspirational in character" and were offered as principles valuable for guidance on ethical issues. Id. Finally, the "Disciplinary Rules" were intended to be "mandatory in character" and "the minimum level of conduct below which no lawyer can fall without being subject to disciplinary action." Id.

53. The Model Rules continued the ABA's movement toward rule-based treatment of legal ethics issues by its adoption of a familiar Restatement-like presentation, with a concise statement of a rule followed by commentary, and by the abandonment of Ethical Considerations employed in the Code. Even so, the drafters of the Model Rules note that two types of rules are included in the work. Most are mandatory and describe the level of conduct below which a lawyer could expect to be disciplined. Others are offered for guidance only, such as Model Rule 6.1 urging lawyers to provide pro bono legal services to the needy. Model Rules of Prof'L Conduct Scope (1983). The Comments are also intended to provide lawyers guidance on ethical issues rather than to impose additional obligations. Id.

54. Fred C. Zacharias, The Humanization of Lawyers, 2002 Prof. Law. (Symposium Issue) 9, 23 [hereinafter Zacharias, Humanization] ("Commentators have noted that, for quite some time, professional regulation has followed a trend of becoming 'legalized'-more specific and designed for enforcement."); 
Perceiving the irony in the fact that lawyers' ethics have been said to be in decline at the same time that regulation of their conduct has become legally more demanding through rules and codes of ethics, ${ }^{55}$ some authors have concluded that the regulatory approach not only has been ineffectual but may itself have contributed to the decline. ${ }^{56}$ The rules and codes have thus become the focus of attention, not for being too lenient or for being inadequately enforced, but for their very nature as mandatory regulatory controls.

A number of commentators take issue with the legalistic content of the present ethical rules and codes. Professor Fred Zacharias refers only to some of the rules in making his criticism along these lines. He notes that, unlike other bodies of regulatory law, many ethical "rules" are intended to serve only as guidance to lawyers on issues for which there exists within the bar no clear consensus as to the correct answer. ${ }^{57}$ He maintains that these rules should not be viewed as regulating behavior but only as influencing it, ${ }^{58}$ and thus they must be drafted with a level of certainty appropriate to this purpose by stating the criteria relevant to the lawyer's determination of the proper course of conduct and even by setting the priorities among those relevant criteria. ${ }^{59}$ Professor Zacharias believes that by failing to do this and by being too specific in these situations an ethics rule creates the appearance of being "all

Fred C. Zacharias, Specificity in Professional Responsibility Codes: Theory, Practice, and the Paradigm of Prosecutorial Ethics, 69 Notre Dame L. Rev. 223, 223 (1993) [hereinafter Zacharias, Specificity] ("Over time, the professional codes governing lawyer behavior have become statutory in form [and] increasingly tell lawyers how they must act."); see also Geoffrey C. Hazard, Jr., The Future of Legal Ethics, 100 YALE L.J. 1239, 1241 (1991) [hereinafter Hazard, Future] ("[The profession's] norms have become 'legalized."'). It has also been noted that the American Law Institute's publication of the RESTATEMENT (THIRD) OF THe LAw Governing LAWYeRs (1998) [hereina fter Restatement], while not a product of the organized bar nor adopted as rules by state supreme courts, continues this movement toward a more rulebased treatment of legal ethics. Wolfram, Legalization of Legal Ethics II, supra note 50, at 205-06.

55. Professor Heidi Li Feldman observes that the increase in the rule-based regulation of lawyers' conduct may itself be evidence of the decline in their ethical behavior. Heidi Li Feldman, Codes and Virtues: Can Good Lawyers Be Good Ethical Deliberators?, 69 S. CAL. L. Rev. 885, 944 (1996).

56. Id. at 886-87; Jones, supra note 3, at 1282-83; Reed Elizabeth Loder, Tighter Rules of Professional Conduct: Saltwater for Thirst?, 1 Geo. J. Legal Ethics 311, 311-12 (1987).

57. Zacharias, Specificity, supra note 54, at 234, 240-41.

58. Professor Zacharias asserts that often ethical codes "truly intend to avoid objective rules for behavior and seek to leave the determination of appropriate conduct to individual lawyers' own consciences." Id. at 238. Similarly, Professor Reed Elizabeth Loder believes that a code "should raise, but not definitively answer, some of the more difficult moral questions about the practice of law." Loder, supra note 56 , at 330 . She envisions the behavior of lawyers being guided by "[a]n open-ended statement of professional ethics" more akin to a constitution than a code of rules. Id. at 333-34. She continues that "[m]ore like poetry than assertion in some of its language, such a document would only point a way to better lawyering." Id. at 334.

59. Zacharias, Specificity, supra note 54, at 245-46. 
inclusive, ${ }^{, 60}$ deters lawyers from engaging in independent reflection about the proper course of conduct, ${ }^{61}$ and engenders suspicions about the motives of the drafters of the rules. ${ }^{62}$ Therefore, in his view, the trend toward legalistic rules of legal ethics has gone too far, ${ }^{63}$ at least in attempting to cover issues not clearly resolved by the organized bar. ${ }^{64}$

Professor William Simon extends this criticism of the current rule-based regulation of legal ethics. ${ }^{65}$ He argues that lawyers have "a professional duty of reflective judgment." ${ }^{\circ 6}$ Expanding on the notion of professionalism embraced by Professors Cramton and Lawry discussed above, ${ }^{67}$ Simon asserts that, at least in civil practice ${ }^{68}$ lawyers should be allowed and even expected to exercise their ethical discretion so as to facilitate just outcomes, despite the negative effect those efforts might have on their clients' interests. ${ }^{69}$ Using the lessons of legal realism, ${ }^{70}$ Professor Simon views ethical rules as being necessarily indeterminate, requiring lawyers to ascertain both their meaning and application. To the extent rules attempt to address this problem through greater specificity, they "tend to be both overinclusive and underinclusive relative to their purposes" $"$ and "tend to prohibit desirable conduct, permit undesirable conduct, or both." ${ }^{, 72}$ Thus, Professor Simon argues that ethical codes should instead consist of rebuttable presumptions rather than categorical

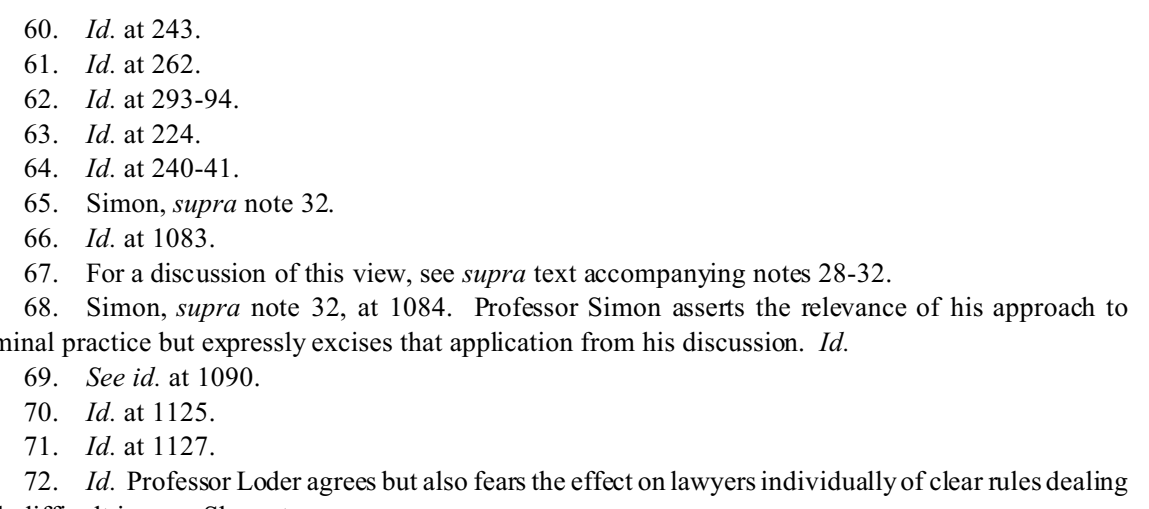
with difficult issues. She notes:

Unless one assumes that drafters can discover particular rules which satisfactorily rest on universal principles, mandatory rules will create inevitable crises of conscience for morally engaged lawyers. One lawyer's relief from moral alienation in a given situation may be another lawyer's anguish. On the other hand, by cutting off moral alternatives, such rules may actually discourage moral reflection in other lawyers. These lawyers may fail to appreciate fully the problems with following an institutional "conscience" and, through regularly following rules without reflection, may lose the ability to identify and criticize moral alternatives.

Loder, supra note 56, at 319. 
rules. $^{73}$ Such an approach to ethical issues would have lawyers utilize their discretion in the same way they do in determining their conduct under the common law principles applicable to legal malpractice. ${ }^{74}$ While the "rules" under this approach would look much different than the present ones, lawyers would still be subject to professional discipline but only for careless or bad faith application of the applicable presumptions. ${ }^{75}$ Professor Simon believes that this approach would further the lawyer's duty as an officer of the court, ${ }^{76}$ another way of characterizing the lawyer's professional duty to the procedures and institutions of the law.

Finally, some commentators take this line of criticism of ethical rules and codes to its logical conclusion, arguing that these legalistic approaches are inherently antithetical to ethical behavior by lawyers and urging their abandonment. Some of these critics assert that ethical codes in business and the professions have little to do with normative ethics in the philosophical sense $^{77}$ and create the false impression that ethical decision-making is coterminous with rule compliance. ${ }^{78}$ Professor Heidi Li Feldman is particularly concerned about the nature of lawyers' responses to ethics codes. $^{79}$ She maintains that legalistic ethics $\operatorname{codes}^{80}$ elicit in lawyers a technocratic approach to ethical issues, which permits them to reach predetermined outcomes generally serving their clients' interests. ${ }^{81}$ What

73. Simon, supra note 32, at 1132.

74. See id. at 1127. Professor Simon also likens the lawyer's discretion under his approach to that exercised by judges in applying the law, $i d$. at 1090-91,1121-22, by prosecutors in seeking the objective of justice, $i d$. at 1091, 1093, and by pro bono lawyers in deciding which cases to accept, $i d$. at 1094. Other writers have touted the advantage of open-ended rather than clear rules, particularly in the area of corporate representation. Richard W. Painter \& Jennifer E. Duggan, Lawyer Disclosure of Corporate Fraud: Establishing a Firm Foundation, 50 SMU L. REv. 225, 270 (1996). It is thought that such rules will prompt the development of common law precedent. $I d$.

75. Simon, supra note 32, at 1132.

76. Id. at 1091 .

77. Professor Feldman describes "normative ethics" as "the field that questions how we should live, what we ought to do, what is morally good and morally right." Feldman, supra note 55, at 887.

78. Steven R. Salbu, Law and Conformity, Ethics and Conflict: The Trouble with Law-Based Conceptions of Ethics, 68 IND. L.J. 101, 104, 130-31 (1992).

79. Feldman, supra note 55.

80. Professor Feldman focuses on the ABA's 1983 Model Rules, which she perceives to be statutelike in form and, in this respect, to be a change in style from the ABA's earlier efforts at codifying legal ethics. Id. at 888. It could be said, however, that the Disciplinary Rules of the ABA's 1969 Code were as statutory in form as the Model Rules. See supra note 52 for a discussion of the nature of the Code's Disciplinary Rules.

81. Professor Feldman sees the technocratic approach as one "which allows a lawyer to generate arguments either way on any given issue." Feldman, supra note 55, at 903 n.56. A lawyer uses the approach "to develop arguments in favor of an outcome chosen independently of ethical concerns. In other 
troubles Professor Feldman is that the approach deters lawyers' sentimental responses to professional issues and discourages good ethical deliberation by them. Her solution is to replace ethical codes with an "institutionalized common law of lawyers' ethics" in which juries would determine the propriety of lawyers' actions through civil litigation of private causes of action brought by those claiming to have been injured by the misconduct. ${ }^{82}$

These commentators and others ${ }^{83}$ present provocative critiques of the present regulatory approach to lawyers' ethics. They differ in the degree of their dissatisfaction with the current ethical codes and in the reach of their proposed solutions. What they share is a belief that the bar's present broad reliance on legalistic rules to regulate lawyers' conduct has gone too far and, to a greater or lesser extent, has had a negative impact on lawyers' ethics. Most important, in varying degrees, the proponents of this approach share the conviction that the present ethical codes should offer broader discretion to lawyers to deliberate on the resolution of important ethical issues.

This deliberative approach ${ }^{84}$ for addressing the perceived decline in lawyers' ethics seeks to reduce the current reliance on statute-like rules and codes in order to obtain this broader discretion for lawyers facing troubling issues of legal ethics. This approach will allow a lawyer to reflect and deliberate on the proper course of conduct, the contention goes, resulting in personal and professional benefits for the lawyer ${ }^{85}$ as well as collective benefits for the bar. ${ }^{86}$ Presumably, the ultimate impact of the approach would

words, technocratic analysis is not usually a method of ethical deliberation; rather it is an instrumentalist alternative to it." $I d$. She also concludes that a "technocratic lawyer is a kind of legal minimalist. She aims essentially for instrumental efficacy in accomplishing goals set by her client." Id. at 886 .

82. Id. at 945 .

83. Included in this group are Jones, supra note 3, Loder, supra note 56, and Salbu, supra note 78.

84. Professor Simon uses the term "discretionary approach" for his proposal. Simon, supra note 32, at 1090. He describes the "basic maxim" of this approach to be that a "lawyer should take those actions that, considering the relevant circumstances of the particular case, seem most likely to promote justice." Id. I use "deliberative approach" to refer more broadly to proposals seeking to increase lawyers' discretion as a way to promote more ethical conduct by lawyers. I do this without embracing the assertion that lawyers operate under a duty requiring affirmative steps to achieve a just outcome. In this sense, Professor Simon's "discretionary approach" would be a more demanding example of a "deliberative approach" as I use that term here.

85. Loder, supra note 56, at 333 (“A statement of professional ethics which presents a picture of the good lawyer and suggests, but does not impose, solutions to some difficult moral problems might stimulate critical reflection and dialogue which make moral development possible.").

86. Id. at 335 ("If the [open-ended statement of professional ethics] enhances lawyers' awareness of the moral complexity of situations they face in practice, the document might bring the profession closer to refined moral understanding. Such a statement of professional ethics would have the potential to promote the kind of critical reflection that encourages moral evolution.”). 
be to encourage more ethical conduct among lawyers, ${ }^{87}$ halting the perceived decline in lawyers' ethics and benefitting society more broadly.

\section{Expecting Too Much}

The professionalism response and the deliberative approach to the perceived decline of lawyers' ethics reflect their proponents' shared dissatisfaction with the effect of the present codes of legal ethics in elevating lawyers' conduct. Those calling for greater professionalism believe that to act in a more ethical manner, lawyers need aspirational urging in addition to the dictates of the present rules. On the other hand, those promoting the deliberative approach find fault in the very use of legalistic ethical codes to govern lawyers' behavior. ${ }^{88}$ Their solution rests in freeing lawyers from such rules to allow them to deliberate individually on the propriety of their conduct.

The two approaches share a common assumption as well. Both theories assume that lawyers, encouraged by appeals to their professional conscience or freed from legalistic codes and rules, will opt for more ethical conduct. For most proponents of these theories, "more ethical conduct" would mean behavior that is less adversarial and more concerned about non-client entities, such as opposing parties and society, and about achieving just outcomes. In short, the proponents believe that lawyers will respond to these approaches by suppressing their zeal in the representation of clients. To evaluate the

87. Some proponents of the deliberative approach see value in the very act of deliberation, independent of any change in the lawyer's pro-client behavior. Feldman, supra note 55, at 937 ("Even though fine ethical deliberation may not produce ethically perfect conduct, such deliberation is in itself a laudable achievement...."). Professor Feldman contends that there is no "shared, complete account of normative ethics by which to judge" the ethics of lawyers' actions, causing her to focus instead on "the character of the lawyers' ethical deliberation." Id. at 929.

88. As noted above, certain critics of the present rules of legal ethics take aim at only some of the rules, such as those that are intended to be for lawyers' guidance and are not well suited for disciplinary enforcement. Professor Zacharias takes such an approach to the issue. See supra text accompanying notes 57-64. Professor Loder also recognizes that specific rules may be necessary, even on difficult moral questions of professional conduct which would otherwise seem unsuited for specific rules. Loder, supra note 56 , at 325 . She asserts that, even on such issues, mandatory rulemaking is warranted "if external considerations, such as the need to protect the public from a client's acts or from the self-interest of lawyers," are present. Id. In fact, Professor Loder expressly notes that "public protection may demand stricter rules despite, or even due to, such [moral] complexity." Id. at 324. Other commentators find fault with the very use of legalistic codes as devices to control the legal ethics oflawyers. Professors Simon and Feldman so contend. See supra text accompanying notes 65-84. For purposes of this discussion, I will refer to the "deliberative approach" as urging a retreat from the present use of codes of legal ethics broadly, while recognizing that some commentators who are critical of the legalistic tone of the present rules would not urge such a broad retreat from ethical codes altogether. 
viability of the professionalism response and the deliberative approach as methods of improving the ethical conduct of lawyers, it is helpful to explore why contemporary lawyers are so zealous in pursuing their clients' interests.

Some critics of the profession might conclude that this zeal is the product of simple venality and avarice among lawyers. If this is correct, the profession indeed is disproportionately made up of miscreants and others with fundamentally flawed characters, as is often posited by the media and humorists. Under these circumstances, it is hard to imagine what can be done to elevate lawyers' ethics except to screen candidates for admission to law school and the bar more rigorously and increase efforts to exclude from the bar those incapable of acting appropriately.

Neither I nor, I suspect, the proponents of the two approaches generally have such a dismal opinion of lawyers. Indeed, a more optimistic view of lawyers is essential to the efficacy of both the professionalism response and the deliberative approach and must be viewed as a fundamental premise of both theories. There is reason to believe that most lawyers try in good faith to follow their professional obligations, though at times their behavior may be troubling, ${ }^{89}$ and that, no less than others in society, lawyers try to do the right thing. ${ }^{90}$ The source of lawyers' zeal must be something other than the profession's mythical greed and moral shortcomings as are bundled into the stereotypical view of lawyers.

Those promoting the professionalism response tend to see the reported excessive zeal among contemporary lawyers as the product of circumstantial factors. Among those factors are the great increase in the number of lawyers in the country during the past thirty years, making competition for available legal fees more intense. ${ }^{91}$ Similarly, another factor would be the economic

89. In describing what he believes was inappropriate behavior by the lawyers in responding to client fraud in the notorious OPM Leasing matter, Professor Lawry notes that the lawyers consulted with outside counsel to determine the ethical course of conduct under the circumstances. Lawry, supra note 29, at 328. He concludes that "[f]rom what we can learn, they all seemed to want to do the 'ethical thing,' going so far as to hire an 'expert' and following his advice to the letter." Id. at 332 .

90. See Daicoff, supra note 4, at 1409 ("While there is evidence to suggest that [lawyers'] stage of moral development and decision-making styles maybe more homogeneous than the general population and more focused on maintaining rules, regulations, social order, and conformity, there is also evidence that their state of moral development does not differ from the moral development of other similarly educated adults. ..." (footnote omitted)); Zacharias, Specificity, supra note 54, at 234-37. On the other hand, I also agree with another conclusion of Professor Zacharias that it is a fiction to believe that lawyers are better people than other citizens. Fred C. Zacharias, The Future Structure and Regulation of Law Practice: Confronting Lies, Fictions, and False Paradigms in Legal Ethics Regulation, 44 ARIz. L. Rev. 829, 844-47 (2002) [hereinafter Zacharias, Future Structure].

91. Daicoff, supra note 4, at 1422. 
changes that have made law firms bigger and more focused on profitability, ${ }^{92}$ leading to such unfortunate trends as increased billing requirements for new associates at the same time that mentoring efforts for those associates have declined. ${ }^{93}$ Professionalism proponents also point to the line of Supreme Court cases $^{94}$ that opened the doors to more aggressive advertising and solicitation. ${ }^{95}$ Some also note that law school faculties have drifted from their old function of providing their students with professional role models and the teaching of legal doctrine. ${ }^{96}$ Instead, the observation goes, law professors now employ forms of analysis showing disregard and even contempt for legal doctrine at the same time that faculties have become distanced from, perhaps even antagonistic toward, the organized bar. ${ }^{97}$ These and other trends, according to the proponents of the professionalism response, have caused lawyers to lose touch with their profession as a calling, to practice law as a mere business, and to engage in overly zealous behavior on behalf of their clients.

If the source of the perceived decline in lawyers' ethics can indeed be found in such formidable circumstances, it is questionable whether the devices

92. Id. at 1424-25; see also Edward D. Re, The Causes of Popular Dissatisfaction with the Legal Profession, 68 ST. John's L. Rev. 85, 86-89 (1994); William H. Rehnquist, The State of the Legal Profession, Legal Econ., Mar. 1988, at 44, 44.

93. Glendon, supra note 12, at 27; KRONMAN, supra note 12, at 295-96; The Second Driker Forum for Excellence in the Law, supra note 7, at 121-22 (remarks of Anthony T. Kronman).

[T] he older ethos of craftsmanship which was nourished and reinforced in a very deliberate and careful way by lawyers in these firms a half century ago has disappeared, and has been replaced by an ethos of moneymaking which puts the exclusive stress mark on the number of billable hours that you put in and the number of dollars those billable hours produce.

Id. An informative description of the trends in large corporate law firms is found in ANDREw L. KAUFMAN \& David B. Wilkins, Problems in Professional Responsibility for a Changing Profession 770-76 (4th ed. 2002).

94. The cases began with Bates v. State Bar of Arizona, 433 U.S. 350 (1977), in which the Supreme Court held that print advertising of routine legal services was commercial speech protected by the First Amendment. Other significant cases include Zauderer v. Office of Disciplinary Counsel, 471 U.S. 626 (1985) (finding newspaper advertising of legal services pertaining to specific subjects of litigation is protected speech), and Shapero v. Kentucky Bar Ass' $n$, 486 U.S. 466 (1988) (finding direct mail solicitation of those known to be in need of legal services is protected speech).

95. Chief Justice Burger so argued. See Burger, supra note 6, at 5 (" $[\mathrm{P}]$ ossibly even worse in its long-range impact than courtroom misconduct ... is the outrageous breach of professional conduct we see in the huckster advertising of some attorneys."). An ABA commission appointed to study the effects of advertising on the public image of lawyers concluded that, while the profession believed that advertising had a negative effect on that image, the public seemed unconcerned by it. The report is discussed in James Podgers, Sorting Out Image, Ads, Ethics, A.B.A. J., Mar. 1995, at 94.

96. KRONMAN, supra note 12, at 264-70.

97. Glendon, supra note 12, at 217-18; see also Kronman, supra note 12, at 230, 240. 
the professionalism proponents rely upon offer much promise as solutions. ${ }^{98}$ The substantial realities of economic competition, profit and loss issues within law firms, and trends in academia are not likely to be overcome by impassioned exhortations at professional meetings and in bar journals, precatory professionalism and civility codes, or greater emphasis on professional values in law school programs and continuing legal education courses. Such efforts at inculcating professional values may ease the collective conscience of the organized bar and suggest to the public that the profession is making an effort. They do not, however, inspire much confidence as devices likely to overcome the market pressures and competitive environment of modern day law practice and the shortcomings of contemporary legal education..$^{99}$

As noted above, those endorsing the deliberative approach see the seeds of lawyers' excessive zeal in the statute-like rules and codes of legal ethics themselves. If, as the legal realists maintain, the indeterminacy of law allows and encourages lawyers to shape their advice and assistance to arrive at predetermined outcomes, the argument goes, the law of legal ethics certainly is no exception. Indeed, the proponents of the deliberative approach would say it is worse. Not only does that law, like law generally, allow lawyers to reach the outcomes they seek for their clients, but the proponents also maintain that by reducing ethics to black letter imperatives, the rules and codes of legal ethics discourage lawyers from reflecting on the virtue of their conduct and separate them from moral responsibility for their behavior. Thus viewed, the rules are the very source of the problem of lawyers' excessive zeal, not its solution.

98. Levine, supra note 7, at 220-21 ("[T] declaration of religious belief . . . [T] he approach of the believers, perhaps useful in preaching to the converted, is unlikely to be an effective means of convincing nonbelievers that such faith in legal professionalism is justified.").

99. In thinking about the possible impact of education in emphasizing or inculcating values, one can reflect on the recent, tragic disclosures of sexual abuse of parishioners by members of the clergy of, and the subsequent mishandling of complaints regarding these incidents by, the Roman Catholic Church. It would be difficult to imagine a subsection of society more systematically trained in values than the Catholic clergy, yet the alleged widespread misconduct and inadequate responses thereto were violative of the most basic moral principles. Surely the sheer number of these incidents warrants caution in speculating about the likely success of additional mandatory values education. At least one former clergyman convicted of such behavior, however, blames a "lack of sexual education in the seminary," claiming that "it should have addressed boundaries and the issues of homosexuality, heterosexuality and even pedophilia." Associated Press, Former St. Cloud Diocese Priest Writes Book About Abuse, BrAINERD DisPATCH (Brainerd, Minn.), July 26, 2002, available at http://www.brainerddispatch.com/stories/072602/sne_0726020001.shtml. 
However, viewing the indeterminate nature of the law of legal ethics as the origin of lawyers' zeal on behalf of their clients begs a critical question: If law is indeterminate and subject to manipulation by lawyers to achieve a predetermined outcome, why do lawyers so universally choose to interpret the law to further their clients' interests? When considering the substantive and procedural law applicable to a client's matter, a lawyer's use of that law's indeterminacy would understandably favor the client's interests rather than those of the client's actual or anticipated adversary. As an illustration, we might think of the situation in which a client approaches a lawyer with a question regarding the application of a governmental regulation to business conduct the client proposes. The indeterminacy of that regulation allows the lawyer room to frame the legal question, interpret facts, and construe the regulation's language to arrive at a conclusion and to give advice that furthers the client's interest in proceeding with the conduct.

When the issue involves the law of legal ethics, a lawyer is interpreting the law applicable to her own conduct, and the lawyer's manipulation of that law's indeterminacy so as to further her client's interests would seem to be less of a foregone conclusion. To be sure in many, perhaps most, instances the lawyer's own interests are also served by constructions of the law of legal ethics that favor the client's interests as well. In some situations, however, this will not be true, and the lawyer will thus feel conflicting pressure from her own interests and values. When considering the law governing the lawyer's own conduct, it would seem plausible that some significant proportion of lawyers would exploit the law's indeterminacy to reach conclusions that would further these other interests rather than those of the client. More specifically, in some cases at least, it would seem likely that these interests would include the lawyer's own desire to serve the institutions and procedures of the law, if this is a fundamental component of a lawyer's professional behavior. Indeed, for some lawyers these personal interests or values would include the lawyer's own moral commitment to facilitating just results. However, the predominance of complaints about lawyers' excessive zeal on behalf of clients suggests that lawyers rarely give in to such personal, moral, and professional interests at their clients' expense.

As an example, a lawyer who represents a client in negotiations with another party may face the issue of whether to respond falsely to a question about the acceptability of a settlement offer by indicating that the client would not agree to the proposal when the lawyer knows this is not true. ${ }^{100}$ The 
Model Rules prohibit lawyers from making false statements of material facts to others while representing a client. ${ }^{101}$ The indeterminacy of that provision offers the lawyer the opportunity to interpret what is "material" in such a way as to justify a deliberate misstatement about the acceptability of the offer, and in negotiations such a response may well serve the client's interests. ${ }^{102}$ The indeterminacy of the law also allows the lawyer to act in such a way as to serve her own interests and values, such as professional values involving the lawyer's duty to serve the procedures and institutions of the law or even the lawyer's own personal morality regarding the impropriety of lying. The lawyer could thus utilize the rule's indeterminacy to conclude that the fact is "material" under Model Rule 4.1 and refuse to lie for the client. Furthermore, if indeed the primary obligation of lawyers is to the institutions and procedures of the law or, stated more boldly, to work toward just results, we might expect a significant proportion of lawyers to react to the indeterminacy of Model Rule 4.1 to serve these values. I suspect that most proponents of the deliberative approach would predict that the lawyer faced with this situation will exploit the ethical rule's indeterminacy to further the client's interests in this situation by making the false statement rather than serving the lawyer's

a more favorable result by denying the existence of settlement authority.

101. Model Rules of Prof'l Conduct R. 4.1 (2003). The Comment to that rule notes that "[u]nder generally accepted conventions in negotiation, certain types of statements ordinarily are not taken as statements of material fact [including] ... a party's intentions as to an acceptable settlement of a claim." Id. R. $4.1 \mathrm{cmt}$. Professor Loder also utilizes Model Rule 4.1 as an example to make her point that the profession would be better off with fewer rules. She views the rule as indicating to lawyers that lies they make in negotiations are not really lies at all. She is thus concerned that the rule "divests the lawyer's actions of moral import." Loder, supra note 56, at 327-28. Professor Paul Haskell seems to agree. PAUL G. Haskell, Why Lawyers Behave As They Do 71 (1998).

102. Professor Haskell offers an explanation of why a lawyer might lie as to a non-material fact in negotiations. He writes:

The point of all this seems to be that the lie does no harm because the person to whom it is directed doesn't take the statement seriously. This is known in the commercial world as puffing and bluffing. The alleged harmless nature of this practice, however, does not stand up to analysis... . If the puff or the bluff is understood to be absolutely false, then it would not influence the behavior of the listener. If the speaker knew this to be the case, there would be no point in his making the statement. Although the listener may discount what the speaker is saying, if the speaker's words are to have any effect, the listener must read into them some risk that the speaker means what he says or means what he says to some extent. The speaker necessarily intends this to be the case. If the speaker is saying something that is not true, but the listener thinks that there is a 20 percent chance that it is true, or some chance that there is a degree of truth in what is said, to that extent the speaker has deceived and the conduct is a lie and is immoral.

HASKELL, supra note 101, at 70-71. 
assumed professional or personal values by avoiding the discomfort of lying. ${ }^{103}$ I would join them in that prediction.

My point is that, while the indeterminacy of the law provides the opportunity for lawyers to pursue a predetermined outcome in favor of their clients, it does not by itself explain lawyers' motivation for doing so when applying the rules and codes of legal ethics to their own conduct and, thus, when their own professional values and moral consciences would seem to control the outcome. The perceived zealous, predominantly pro-client conduct of lawyers in the face of the indeterminacy of the ethical rules suggests something beyond the mere indeterminacy of the codes of ethics operates to promote lawyers' zealous conduct on behalf of their clients at the expense of other personal and professional interests.

What is operating here is lawyers' allegiance to their clients. This allegiance is presently the fundamental characteristic of the lawyer-client relationship. ${ }^{104}$ Having its basis in the law of agency, the relationship is often described as fiduciary in nature and demands the lawyer's loyalty to the client. As the client's agent, a lawyer is generally expected to follow the directions of the client and to serve the client's interests within the bounds of the law. The gravity accorded the lawyer-client relationship is shown in the fact that failure to follow the dictates of this body of law can result in the lawyer's civil liability. ${ }^{105}$ Many of the principles of the agency relationship between the client and lawyer have also been incorporated into the codes of legal ethics, as discussed below, ${ }^{106}$ further cementing the allegiance of lawyers to their clients' interests. ${ }^{107}$ The agency relationship can thus be seen as providing the legal underpinnings for lawyers' zeal on behalf of their clients.

However, the lawyer's role as the client's agent is more than a mere legal obligation. It is also fully incorporated in the narrative of the profession. Taught in the law schools of the nation, both consciously and

103. Professor Loder suggests considering the use of such false statements as the profession's "standard procedure." Loder, supra note 56, at 328.

104. Professor Wolfram asserts that this has not always been the case and is really a shift from a more independent role of lawyers that has occurred since the mid-nineteenth century. Wolfram, Legalization of Legal Ethics II, supra note 50, at 220-21.

105. Restatement (Third) of the Law Governing Lawyers $\S 49$ (2000) (“[A] lawyer is civilly liable to a client if the lawyer breaches a fiduciary duty to the client. ...").

106. See infra text accompanying notes $130-43$ for this discussion.

107. Professor Zacharias has observed that " $[t]$ he principle of zealous advocacy is punctiliously obeyed - sometimes as a means for justifying conduct the lawyers wish to pursue, but often because of the engrained sense that client-centered behavior is ethically required." Zacharias, Specificity, supra note 54, at 236 n.40. Lawyers' commitment to their clients' interests has been characterized as the "dominant view of legal ethics." Perlman, supra note 11, at 986. 
unconsciously, ${ }^{108}$ and embraced in frequent public tributes to the legal profession, ${ }^{109}$ the notion of loyalty to and zeal on behalf of clients forms the dominant filter through which lawyers view their work.

Not insignificantly, the personal allegiance that develops between lawyers and their clients also furthers the legal components of the agency relationship and the professional narrative that incorporates it. It is natural, even laudable, that lawyers align themselves with the people who have sought, and usually pay for, their professional assistance. Lawyers' identification with their clients' cause is additionally encouraged by the formal policies and practical pressures of the institutions through which they practice, including law firms, government agencies, corporations, and legal aid offices, bringing lawyers' financial and other career interests into line with the legal and professional concept of zealous advocacy. ${ }^{110}$

Client allegiance, which is fundamental to the lawyer-client relationship, can thus be seen as the default principle of the legal profession. ${ }^{11}$ Clients retain lawyers as their agents to serve their interests and to do so competently,

108. It has been noted that law student opinions on the role of lawyers in society shifts during law school, with third year law students being more drawn to the role of the lawyer as zealous advocate than first year students. J.D. Droddy \& C. Scott Peters, The Effect of Law School on Political Attitudes: Some Evidence from the Class of 2000, 53 J. LEGAL EDUC. 33, 35 (2003).

109. Perhaps the most famous of these tributes is that of Lord Henry Brougham, who said: [A]n advocate, in the discharge of his duty, knows but one person in all the world, and that person is his client. To save that client by all means and expedients, and at all hazards and costs to other persons, and, amongst them, to himself, is his first and only duty: and in performing this duty he must not regard the alarm, the torments, the destruction which he may bring upon others.

David Mellinkoff, The Conscience of a Lawyer 189 (1973) (quoting 2 H.L. Jour. 8 (1828) (Trial of Queen Caroline)).

110. It is significant that lawyers' own economic interests generally are served by their pursuit of client interests. Professor Lawry discusses lawyers' willingness to ignore and even participate in their clients' fraudulent activities in the OPM Leasing case, Lawry, supra note 29, at 327-31, and offers two reasons for the lawyers' conduct:

The first is their almost pathological pro-client attitude, backed by a narrow reading of the Code of Professional Responsibility. The second is tied to the first. It is the lawyer's economic interest. Whatever the pro-client stance means in psychological or moral terms, the economic factor is hidden not too far from the surface. Id. at 330 .

111. Professor Haskell summarizes the situation by noting:

The professional rules permit the lawyer to accept or decline representation, but once representation has been accepted, the lawyer becomes a fiduciary of the client for the purpose of achieving the client's objective. The lawyer owes her client exclusive and zealous dedication to his interest in order to obtain for him all that the law allows - and ... sometimes more than the law allows.

HASKell, supra note 101, at 51. Professor Wolfram notes in his treatise that descriptions of the lawyers as pro-client, zealous advocates "reflect the dominant, although hardly universal, professional ethic." WOLFRAM, supra note 51, at 580 . 
loyally, and, indeed, zealously. The law supports this notion as do the norms of the profession, the pressures of the natural personal relationships between lawyers and clients, and the dynamics of institutions in which lawyers practice.

To recognize the dominance of the powerful relationship that exists between lawyers and their clients is not to say that the lawyer's zeal on behalf of a client should remain unchecked or that other principles should never be viewed as warranting appropriate limits upon it. ${ }^{112}$ It is merely to observe that the legal, professional, and personal underpinnings of the agency relationship between lawyers and their clients generate lawyers' predisposition toward zeal on behalf of those clients. ${ }^{113}$

The intensity of the lawyer-client relationship also enlightens us about lawyers' likely reactions to the two approaches to the perceived problems of excessive zeal. The deep legal, professional, personal, and practical roots of the lawyer's allegiance to the client do much to explain the resistance of lawyers to aspirational exhortations urging greater restraint on their zeal and

112. Proposals to use the law of legal ethics to accomplish a better balance between zealous advocacy on behalf of clients and obligations to other interests will be discussed later in this paper. See infra Part V.

113. The question might be asked why contemporary lawyers are viewed as being more zealous than lawyers of earlier eras, the basic contention of those perceiving a professionalism crisis within the legal profession. While it was noted above that it was not important for purposes of this discussion to resolve the issue of whether the purported crisis was real or imagined, see supra text accompanying notes 4-11, some theories might be offered as possible and plausible responses to this question. First, those who observe a decline in lawyers' ethics may simply be wrong. Some commentators have opined that those proclaiming a crisis in contemporary lawyers' professionalism are longing for an era of better ethics within the legal profession that never really existed. See supra text accompanying note 10 . Second, if there has been an increase in lawyers' zeal during the last three decades of the twentieth century, it may reflect increasingly stringent adherence to the zealous advocate model in the applicable law. This may be shown in both the law of legal ethics and the law of lawyer malpractice. The law of legal ethics has shifted from the aspirational sta tements of general guidance that made up the ABA's 1908 Canons of Professional Ethics to two codifications of legal ethics in the subsequent 1969 Model Code of Professional Responsibility and the 1983 Model Rules of Professional Conduct. The latter two efforts of the ABA could fairly be characterized as embracing the zealous advocate role of lawyers, with few restrictions on that role that can be said to favor the public interest. This is a point I made at length in an earlier article. Eugene R. Gaetke, Lawyers as Officers of the Court, 42 VAND. L. REV. 39 (1989). The law of legal malpractice has become more demanding of lawyers as well, perhaps causing the shifts in professional attitudes regarding devotion to the client's interests. Charles W. Wolfram, Toward a History of the Legalization of American Legal Ethics-I. Origins, 8 U. CHI. L. Sch. RoundTABLE 469, 482-84 (2001) [hereinafter Wolfram, Legalization of Legal Ethics I]. Third, shifts in lawyers' behavior toward conduct that is more aggressive and less civil may reflect broader trends in society occurring at the same time. It is hard to observe current behavior in political campaigns, talk shows, sports commentaries, situation comedies, and instances of road rage, for example, without concluding that broader societal forces are at work in affecting civility within the legal profession as well. 
suggest that these tactics of the professionalism response are likely to be unsuccessful.

The pressures of the lawyer-client relationship also provide helpful insight into the deliberative approach. In the face of the institutional and personal expectations and pressures of that relationship, lawyers understandably utilize the indeterminacy of substantive and procedural law to arrive at pro-client legal positions and advice. Furthermore, as the proponents of the deliberative approach maintain, the indeterminacy of the codes of legal ethics leads to similar tendencies when lawyers face issues of professional conduct in fulfilling their agency duties to their clients. This occurs not as the mere result of the indeterminacy of the law, but because of the backdrop of the pro-client obligations, professional pressures, and personal tendencies that make up the lawyer-client relationship. Given the importance of that relationship, it is understandable that lawyers will use the indeterminacy of the rules and codes of legal ethics to pursue their clients' objectives. ${ }^{114}$

What is not understandable, however, is why the proponents of the deliberative approach would expect lawyers to be less zealous on behalf of clients if their discretion as to ethical matters were expanded through a reduction in or abandonment of the bar's reliance on legalistic ethical codes. The legal, professional, economic, and personal reality of the agency relationship between the lawyer and client would be at least as likely to result in pro-client resolutions and actions in lawyers' exercise of that discretion if it were it to be broadened. ${ }^{115}$ Indeed, one might reasonably expect lawyers' zealous pursuit of their clients' interests, left unfettered by ethical rules and codes, to become more intense rather than less so.

The history of the regulation of the profession supports this assumption. In a pair of interesting articles, ${ }^{116}$ Professor Charles Wolfram divides that history into two parts, ${ }^{117}$ using 1970 as the dividing line. ${ }^{118}$ This date roughly corresponds with the ABA's adoption of the Model Code of Professional

114. It cannot be denied that often the client's interests coincide with the lawyer's personal interests as well, as Professor Zacharias argues. Zacharias, Humanization, supra note 54, at 25; see also Fred C. Zacharias, Reconciling Professionalism and Client Interests, 36 WM. \& MARY L. Rev. 1303, 1331-50 (1995) [hereinafter Zacharias, Reconciling Professionalism].

115. Referring to the context of the practice of law, Professor Deborah Rhode observes that "[i]n these circumstances, people often have a poor grasp of their own reasoning processes." Deborah L. Rhode, If Integrity Is the Answer, What Is the Question?, 72 FordHAM L. Rev. 333, 343 (2003).

116. Wolfram, Legalization of Legal Ethics I, supra note 113; Wolfram, Legalization of Legal Ethics II, supra note 50 .

117. Wolfram, Legalization of Legal Ethics I, supra note 113, at 471.

118. He describes the dividing line as being "somewhat arbitrarily chosen." Id. 
Responsibility in 1969, a body of rules that can be described as the first effort at establishing minimal levels of conduct for lawyers. The pre-1970 period might be characterized, therefore, as one during which few legalistic ethical regulations were imposed on lawyers to restrain their ethical discretion. Even the ABA's 1908 Canons of Ethics were couched in precatory terms and were not generally intended to be the basis of lawyer discipline. ${ }^{119}$ In looking at the pre-1970 period, Professor Wolfram concludes that it is one in which the "discipline of lawyers remained relatively rare." ${ }^{20}$ One possible explanation of this conclusion could be that lawyers behaved better as a result of having more ethical discretion in deciding how to act. Professor Wolfram discounts this possibility ${ }^{121}$ and reminds us that it is this more discretionary period that was being referred to in the ABA's famous 1970 Clark Report, ${ }^{122}$ when it concluded that the discipline of American lawyers was a "scandalous situation." 123 That conclusion undercuts the contention that a return to greater ethical discretion will result in better conduct by lawyers.

Experience with several of the present ethical rules also counsels caution about the ultimate success of the deliberative approach. The current rules already grant considerable discretion to lawyers on a number of important matters. ${ }^{124}$ The rules allow lawyers to decline proffered employment ${ }^{125}$ and to withdraw from representation when clients are using their services to accomplish objectives the lawyers consider objectionable ${ }^{126}$ or when there may be reason to fear that the lawyers would be assisting clients' criminal or

119. Professor Wolfram concludes that " $[\mathrm{t}]$ he chief motivation for the ABA's adoption of the 1908 Canons was probably status seeking by the elite lawyers who constituted the minuscule membership of the ABA." Id. at 485. He also perceives, however, "indications that the ABA also intended the Canons to have an influence (if not direct application) in lawyer disciplinary actions." Id.

120. Id. at 486 .

121. Id. at $486-87$.

122. American Bar Association Special Committee on Evaluation of Disciplinary Enforcement, Problems and Recommendations in Disciplinary Enforcement (1970) [hereinafter Clark Report]. The Committee was chaired by Justice Tom C. Clark and is thus generally referred to as the "Clark Report."

123. Id. at 1.

124. Zacharias, Humanization, supra note 54, at 25. This point is explored further by the same author in Zacharias, Reconciling Professionalism, supra note 114, at 1331-50.

125. No Model Rule requires a lawyer to accept any employment, although lawyers are directed not to seek to avoid appointments by a tribunal to represent persons unless there is good cause for doing so. See Model Rules of Prof'L Conduct R. 6.2 (2003). Under the Model Code's EC 2-26, in order to fulfill the bar's goal of making legal services available to all, employment is not to be "lightly decline[d]" by lawyers. Model Code of Prof'L Responsibility EC 2-26 (1980).

126. Model Rules of Prof'L Conduct R. 1.16(b)(3) (2003). 
fraudulent activities. ${ }^{127}$ The rules also grant lawyers broad power to determine the means by which their clients' objectives are to be met ${ }^{128}$ and, by agreement with the client, even some power to limit those objectives. ${ }^{129}$ These rules offer lawyers meaningful opportunities to temper their zeal, if broad discretion is indeed what will motivate them to do so. Most observers would probably agree, however, that in practice these areas of discretion do little to reduce the zeal of lawyers acting on behalf of their clients. Would broader discretion do more?

The proponents of the professionalism response and deliberative approach to the perceived decline in lawyers' ethics are expecting too much of lawyers. They do not expect too much in seeking to have lawyers restrain their zeal or be more concerned about the interests of those other than their clients. The objectives of both groups of proponents in this respect are unexceptionable. Given the realities of the lawyer-client relationship, however, they are expecting too much of lawyers, and of their theories as well, in envisioning that their approaches will cause lawyers to ignore the real duties, pressures, and allegiances of that relationship in deciding how to act. To be successful, any approach for improving the professionalism of the bar must recognize and contend realistically with the bonds of the lawyer-client relationship as the fundamental default principle of lawyers' representation of clients.

\section{Expecting Too Little}

While the proponents of the professionalism response and deliberative approach expect too much of lawyers in the anticipated reactions to their proposals, they also expect too little. They do this by turning their backs on ethical rules as means to elevate lawyers' conduct. The two approaches thus ignore or reject entirely the most effective, and perhaps only, device available for modifying the legal demands and natural consequences of the lawyer-client relationship, particularly the excessive zeal that characterizes it.

As noted above, the codes of legal ethics and the law of agency both serve to define lawyers' professional conduct. ${ }^{130}$ This fact is most apparent where the ethical codes expressly adopt and thereby reinforce existing agency law

127. Id. R. 1.16(b)(1)-(2).

128. Id. R. 1.2 (a). While the rule grants lawyers the responsibility of determining the means of pursuing clients' objectives, lawyers are expected to consult with their clients regarding these means. Id.

129. Id. R. $1.2(\mathrm{c})$. The rules also grant lawyers the discretion to reveal confidential information if necessary to protect others from their clients' violent crimes. See id. R. 1.6(b)(1).

130. See supra text accompanying notes 106-07 for this discussion. 
principles. The lawyer's duties of loyalty to ${ }^{131}$ and confidentiality on behalf of clients $^{132}$ are obvious examples of parallel, though not identical, requirements from the two bodies of law. ${ }^{133}$ These and other rules of legal ethics work to cement what the law of agency already demands of lawyers in the representation of their clients.

Somewhat less apparent is that the codes of legal ethics also serve to modify and restrict the legal duties of lawyers acting as the agents of their clients. This consequence results from the way the law of agency accommodates the requirements of other sources of law governing agents' conduct. Agency law expressly yields to the demands of other law, expecting agents to act lawfully themselves and to refuse to follow the illegal or unethical instructions of their principals in carrying out their duties. ${ }^{134}$ This approach carves from the lawyer's duty as the client's loyal agent any actions that are criminal or violative of other statutory imperatives or common law duties. ${ }^{135}$

The same principle of deference to other law applies to reconcile the law of agency with the law of legal ethics as it is constituted in the professional rules and codes applicable to lawyers. ${ }^{136}$ In defining conduct expected of lawyers, the legally binding nature of these ethics rules dictates their predominance over the duties imposed on lawyers by the law of agency. Where ethical codes require lawyers to curb their zeal, the general demands of the lawyer-client relationship have been restructured accordingly. ${ }^{137}$

131. Model Rules 1.7 and 1.8, for example, govern the avoidance of certain conflicts of interest, a topic covered by $\S 16(3)$ of the Restatement, supra note 54. See Model Rules of Prof'L Conduct Rs. $1.7 \& 1.8(2003)$.

132. Model Rule 1.6 pertains to confidentiality, which is also a part of the lawyer's duty as an agent. RESTATEMENT, supra note 54, § 16(3).

133. Professor Zacharias reminds us that the current codes of ethics, which permit a range of actions by lawyers that serve their own, rather than their clients', interests, do not universally embrace the fiduciary concept for the lawyer-client relationship. Zacharias, Future Structure, supra note 90, at 852-53. He concludes that "the regulatory paradigm that lawyers always act as fiduciaries thus may be false, or, at least, an overstatement." Id. at 853.

134. The comments to the Restatement note that "[a] lawyer has authority to take any lawful measure within the scope of [the] representation that is reasonably calculated to advance a client's objectives as defined by the client." Restatement, supra note $54, \S 21 \mathrm{cmt}$. e (emphasis added) (citation omitted). The Restatement also applies to lawyers the usual concept of agency law that a "contract by an agent to help the principal to perform an unlawful act is unenforceable." Id. $\S 23 \mathrm{cmt}$. c.

135. Id. $\S 23 \mathrm{cmt}$. c.

136. In determining the lawfulness of a client's directive, the Restatement notes that " $[\mathrm{u}]$ nlawful acts include all those exposing a lawyer to civil or criminal liability, including procedural sanctions, or discipline for violation of professional rules." Id. (emphasis added).

137. Professor Lawry, in evaluating fictional and actual lawyers' reactions to concealment of discoverable documents, for example, notes that "the lawyer's obligation to the client is subordinate to the 
Some examples can be noted from the Model Rules. The rules require lawyers to take "reasonable remedial measures" when they discover the falsity of evidence they previously offered to a tribunal. ${ }^{138}$ Similarly, the Model Rules require a lawyer litigating a matter to disclose to the court any legal authority from the controlling jurisdiction that the lawyer knows to be directly adverse to her client's position if it is not disclosed by her adversary. ${ }^{139}$ The Model Rules also mandate that a lawyer representing a client in ex parte proceedings present all material facts, even those that are adverse to the client, to allow the court to make an informed decision. ${ }^{140}$ These rules expect lawyers to take action that is contrary to the usual dictates of the agency relationship which demand the agent's loyalty and confidentiality in acting on behalf of the principal. When adopted by the state's supreme court as binding law, these ethics rules redefine the lawyer-client relationship and reduce the degree of zeal that it demands of lawyers.

It must be recognized, however, that the existing rules and codes of legal ethics do not provide much in the way of substantial limits on lawyers' zealous representation of their clients. ${ }^{141}$ On the contrary, the course of the regulation of lawyers' behavior during the past one hundred years has not turned appreciably away from the zealous advocate model, despite significant and repeated efforts by some within the bar to impose greater public interest responsibilities on lawyers. In fact, an argument can be made that, in moving from the 1908 Canons of Professional Ethics to the 1969 Model Code of Professional Responsibility and then the 1983 Model Rules of Professional Conduct, the American Bar Association has increasingly embraced and reinforced the zealous advocate model in its rules and that the 40 or so states that have substantially adopted these rules have done the same. ${ }^{142}$ Even renewed attempts to modify the Model Rules at the turn of the 21 st century through the efforts of the Ethics 2000 project resulted in the ABA's House of

\footnotetext{
lawyer's primary obligation to the law." Lawry, supra note 29, at 317-18. The law he refers to in this context is the Code of Professional Responsibility, the relevant body of ethical rules. Id.

138. Model Rules of Prof’l Conduct R. 3.3(a)(3) (2003).

139. Id. R. 3.3(a)(2).

140. Id. R. 3.3(d).

141. Gaetke, supra note 113 , at 61 . It also has been noted that on many important issues, the current rules leave lawyers without sufficient guidance. Robert H. Aronson, Professional Responsibility: Education and Enforcement, 51 WASH. L. REv. 273, 286 (1976) ("The view of professional responsibility as dependent upon the moral responsibility of individual lawyers has resulted in a set of rules which give attorneys little guidance as to what the profession expects of them.”).

142. Gaetke, supra note 113, at 71. For a listing of the states that have adopted the ABA's Model Rules in full or substantial part, see ABA/BNA Law. Manual Prof. Conduct, Manual No. 249, 01:3-8.
} 
Delegates' rejection of certain proposals that would have further reduced the level of zeal expected of lawyers in the representation of their clients. ${ }^{143}$

In August 2003, however, a rash of embarrassing revelations implicating lawyers in recent, stunning corporate scandals motivated the $\mathrm{ABA}$ to reconsider some of the Ethics 2000 recommendations it had rejected just two years earlier. ${ }^{144}$ Despite the strong and negative public reactions to these allegations about lawyers' alleged conduct in the scandals, only by the slimmest of margins ${ }^{145}$ did the organization's House of Delegates adopt amendments to the Model Rules regarding broader permissible disclosures to protect others from client crimes and fraud. ${ }^{146}$ Importantly, by allowing these disclosures to protect the interests of non-clients, these new provisions reduce the degree of client loyalty and confidentiality demanded of lawyers both under the law of agency and the prior version of the ABA's Model Rules. ${ }^{147}$ Equally important, however, is that the new provisions do not mandate such disclosures even in the face of the worst sorts of threatened harm, instead leaving that corrective action to the discretion of the lawyer. ${ }^{148}$

In this respect, the ABA's 2003 amendments can be seen as consistent with both the professionalism response and the deliberative approach to lawyer misconduct. The amendments permit a wider range of lawyer disclosures of confidential information to protect the interests of others,

143. 17 ABA/Bnalaw. Manual Prof. Conduct: Current Reports 492 (2001). Most notably, these proposals included changes in Model Rule 1.6's narrow treatment of exceptions to the confidentiality of information relating to the representation of a client. The Ethics 2000 Commission had recommended that exceptions be provided to permit lawyers to reveal such information to prevent a client from committing a crime or fraud that would harm the financial interests of another or to rectify such harm if the lawyer's services had been used in the client's past commission of such a crime or fraud. Id. The ABA's House of Delegates rejected both proposals in 2001. Id.

144. 19 ABA/BNA Law. Manual Prof. Conduct: Current Reports 467 (2003).

145. $I d$.

146. See Model Rules of Prof'l Conduct R. 1.6(b)(2)-(3) (2003). The ABA also adopted changes to Model Rule 1.13 pertaining to lawyers representing organizations such as corporations. Id. R. 1.13. These changes were more protective of the organizational client's interests than of non-client third persons' interests. For further discussion of these changes, see Rutheford B Campbell, Jr. \& Eugene R. Gaetke, The Ethical Obligation of Transactional Lawyers to Act as Gatekeepers, 56 RUTGERs L. REV. 9 , 21-28 (2003).

147. In referring to a similar discretionary disc losure rule proposed in the Revised Final Draft of the Model Rules, but not adopted as part of Model Rule 1.6 by the ABA in 1983, Professor Lawry describes the provision as an ethical rule that "emphasizes the lawyer's role as an officer of the law and of the legal system itself." Lawry, supra note 29 , at 327.

148. None of the exceptions to Model Rule 1.6's general protection of confidentiality mandates disclosure. See Model Rules of Prof'l Conduct R. 1.6(b) (2003). Thus, whether to disclose confidential information to prevent or rectify a crime or fraud of the client is left to the discretion of the lawyer. See id. 
reducing some of the rules' prior restrictions on such disclosures. For the proponents of the professionalism response, this means that the amendments make more palatable and potentially more successful their calls for lawyers to act with greater concern for the interests of non-clients. With the rules' previous prohibitions on disclosures removed by the new amendments, more lawyers may be likely to respond to such entreaties from the professionalism proponents.

Similarly, because the amendments are permissive only, leaving lawyers with the discretion whether to disclose information in these circumstances, those favoring the deliberative approach should also see the changes in the rules as a step in the right direction. While the previous ABA rule on confidentiality prohibited the disclosure of confidential information to prevent a client from committing fraud upon another, ${ }^{149}$ the new amendments permit, but do not require, such disclosures. ${ }^{150}$ According to the proponents of the deliberative approach, this discretion should encourage more ethical deliberation among lawyers confronting such facts and, if their theory holds true, ultimately result in more ethical conduct as well. ${ }^{151}$ This "more ethical conduct" presumably would mean the greater use of disclosures to prevent harm to non-client third persons.

These 2003 amendments by the ABA have been forwarded to the state supreme courts for consideration. While their future success in the adoption process is a matter of speculation, there is reason to doubt that the ABA's new approach to such disclosures will have much effect in changing lawyers' behavior as to client fraud. In this regard, it is important to note that the existing versions of the Model Rules adopted in most states already permit disclosures in the face of client fraud. ${ }^{152}$ Thus, the 2003 amendments to

149. See Model Rules of Prof'l Conduct R. 1.6(b) (1983).

150. See Model Rules of Prof'L Conduct R. 1.6(b)(2) \& (3) (2003).

151. Even a discretionary rule can raise concerns for advocates of the deliberative approach. Professor Loder, for example, expresses concern that " $[\mathrm{w}]$ here a specific and unitary solution is painlessly available to solve a complicated problem with moral consequences, lawyers might follow, without critical reflection, even a discretionary specific rule." Loder, supra note 56, at 319. The discretionary nature of the ABA's 2003 amendment of Model Rule 1.6, therefore, may not offer promise for all proponents of the deliberative approach.

152. A helpful chart of the states' treatment of confidentiality and disclosures is provided in THомаS D. Morgan \& Ronald D. Rotunda, 2004 Selected Standards on Professional Responsibility 144-55 (2004). Eight states permit or require disclosures under substantially the same circumstances allowing lawyers' disclosure under the ABA's 2003 amended version of Model Rule 1.6 (Hawaii, Maryland, Massachusetts, Nevada, North Carolina, North Dakota, Pennsylvania, and Texas). Id. As the chart's summary shows, 41 states permit or require disclosure to prevent a client's criminal fraud that will result in substantial harm to another's financial interests, 12 states permit or require such disclosures for 
Model Rule 1.6 do not propose significant change to what is already the law in many jurisdictions. To the extent that lawyers in general are viewed as not making enough disclosures to protect non-clients' interests, the level of discretion embraced by the new amendments' treatment of confidentiality is not likely to be the answer to the problem. Furthermore, as noted above in reference to other areas of discretion afforded lawyers by the Model Rules, ${ }^{153}$ more than broad discretion is apparently needed to overcome their duties to clients and cause them to act in favor of the interests of others. The new amendments thus fail to deal with the legal and practical realities of the lawyer-client relationship and continue to expect too little of lawyers.

To expect more, the organized bar must use its own ethical rules to modify the lawyer-client relationship in a way that provides meaningful amelioration of the zeal it now encompasses. ${ }^{154}$ The rules are the only device within the control of the bar to contend with and counter the legal demands and practical pressures inherent in that relationship. However, to date, the bar has not done much to utilize its power to accomplish this end. ${ }^{155}$ The bar's rules have done little to demand of lawyers conduct that subordinates the interests of their clients to other interests, such as those of the public or of the judicial system. ${ }^{156}$ Instead, the rules embrace the zealous advocate model of

civil fraud, and 18 states permit or require such disclosures to rectify or mitigate past client fraud when the lawyer's services were used to commit the fraud. Id. at 149.

153. See supra text accompanying notes 124-29.

154. Burger, supra note 6, at 7 ("We must remember that we are a profession, but we will remain a profession only if our standards command it."). In a related discussion, Professor Haskell notes the importance of rules limiting advocacy to the truth-seeking function of the adversary system. He writes:

If our form of litigation is an ineffective means of determining the truth, it is not because of its adversary nature as such, but rather because of the practices and tactics that are permitted or required. Conflicting advocacy, with proper constraints, can assist in the search for truth. The problem is not the existence of an adversary system, but rather the rules that govern it.

HASKELL, supra note 101, at 55 (emphasis added).

To be sure, not all agree that better rules will be effective in changing lawyers' behavior. Professor Atkinson, for example, notes:

As in matters of religion, so in matters of professional aspiration, we are unlikely to come to full agreement, and we are almost certainly not going to be able to bring other conscientious people to our belief by force of either argument or arms. This is, of course, precisely the premise reached by English liberals of Locke's generation in the wake of the Puritan Revolution and the Stuart Restoration.

Atkinson, supra note 12, at 269 .

155. See supra text accompanying notes 141-48.

156. In addressing this issue directly in its comments to Model Rule 4.4, entitled "Respect for Rights of Third Persons," the ABA declares that "[r] esponsibility to a client requires a lawyer to subordinate the interests of others to those of the client," while obscuring that statement by noting that this "responsibility does not imply that a lawyer may disregard the rights of third persons." Model Rules of Prof'L 
lawyering rather than one that calls for greater concern about non-client interests. Thus, it is no surprise that lawyers act in accordance with that view, failing to respond to calls for greater professionalism and exercising their discretion to serve their clients single-mindedly, even when the rules expressly allow them the discretion to do otherwise. ${ }^{157}$ To counter these tendencies, the bar could modify the rules to provide a different set of expectations for lawyers and to establish a different legal framework for lawyers serving as agents for their clients. ${ }^{158}$

What is most perplexing, perhaps, about the reluctance of the organized bar to utilize ethical rules more aggressively to demand more of lawyers is that it comes at a time when bar leaders so earnestly seek a higher level of professionalism from them. While bar leaders decry the decline in legal ethics among contemporary lawyers in speeches and in promoting professionalism programs, the law of legal ethics continues largely to reflect the zealous advocate model of lawyering. Since the power to demand more of lawyers through the promulgation and enforcement of rules of legal ethics lies so readily and exclusively in the hands of the bar itself, critics and the public are left to ponder the apparent disconnect — some might say hypocrisy—reflected in the bar's approach. While the past failures of the organized bar to embrace a more balanced role for lawyers are not encouraging, viewed as a function of rulemaking and enforcement, success in modifying the role of lawyers as zealous advocates would appear to be within the reach of the bar. Changing the behavior of lawyers can thus be seen as a matter of the organized bar's will.

To those who might say that we have tried this and it has failed, I would say simply that we have not. Indeed, of the three approaches to dealing with the supposed decline of lawyers' ethics that are discussed in this articleprofessionalism response, the discretionary approach, and the adoption and

CONDUCT R. 4.4 cmt. 1 (2003).

157. This tendency of lawyers in the face of discretion already granted them by the rules is discussed above. See supra text accompanying notes 124-29. In addressing the broad discretion allowed by the rules, Professor Luban notes:

It is indeed a matter of political concern when a profession-be it medicine, or public administration, or law - has been underregulated, granted too much power and discretion. But until that is remedied, the professional's discretion, wisely and responsibly exercised, must absorb the moral costs of the system. If the highways are dangerous and poorly policed, drivers must be more responsible and more willing to help each other.

LuBAN, supra note 3, at xviii. this aim.

158. See infra Part $\mathrm{V}$ for a discussion of the sort of changes that would work toward accomplishing 
enforcement of rules that diminish the zeal of lawyers - only the last has not been seriously attempted to date.

\section{Using Rules to Improve Lawyers’ Professionalism}

If contemporary lawyers are overly zealous on behalf of their clients and show insufficient regard for the consequences of their actions on the procedures and institutions of the law, the adoption and enforcement of meaningful rules offer the most hope for reversing that development. Past appeals to lawyers' consciences and the breadth of discretion already permitted under current rules have apparently not helped to elevate lawyers' conduct sufficiently, suggesting that additional similar appeals and broader discretion are unlikely to lead to future improvement. If we are intent on achieving conduct more reflective of professionalism as we have discussed it here, that lawyers' primary duty is to the procedures and institutions of the law, what is needed are rules that restrain the zeal inherent in the lawyer-client relationship and reinforced by the current rules of legal ethics.

\section{A. The Prospect for Compliance}

Even assuming the organized bar could adopt them, the question arises whether lawyers would obey rules that mandated a less zealous approach to the representation of their clients. Given current public attitudes about lawyers, many would not be optimistic. Even within the bar, skepticism would be likely, although this would be ironic indeed from members of a profession that publicly proclaims itself to be made up of officers of the legal system. ${ }^{159}$

An interesting study of why people obey the law, ${ }^{160}$ however, may offer reason for more optimism. That study, involving a random sample of 1,575 citizens of Chicago, ${ }^{161}$ criticizes common instrumental views of compliance, which posit that peoples' behavior is "motivated by self-interest" and which lead to a preoccupation with "manipulation of behavior through the control of punishments and incentives." "162 It sees such views as inadequate to explain what really determines citizens' desire to comply with the law. ${ }^{163}$ Instead, the

159. See Model Rules of Prof'L Conduct Preamble (2003).

160. Tom R. Tyler, Why People Obey the Law (1990).

161. Id. at 8 .

162. Id. at 165 .

163. The author notes: 
study found that people focus on "normative issues,"164 such as "the legitimacy of legal authorities and the morality of the law." "165 The author of the study concludes that "[p]eople are more responsive to normative judgments and appeals than is typically recognized by legal authorities. Their responsiveness leads people to evaluate laws ... . in normative terms, obeying the law if it is legitimate and moral." ${ }^{166}$ If this is true for citizens in general, there is reason to believe or at least hope that the same conclusion could be reached about lawyers and the rules that govern them. ${ }^{167}$

What the Chicago study suggests for this discussion is that lawyers will be more likely to obey new rules regarding professional behavior if the rules reflect values that are moral in their content and are legitimate in the sense that they are supported by a consensus within the bar. Neither of these objectives would be easy to achieve. Lawyers' notions of morality, or what is "right and proper," undoubtedly reflect the current professional conception of lawyers as zealous advocates, and efforts to adjust that role will likely be met with views that the proposed changes are immoral, wrong, and improper. For the same reason, securing a consensus within the organized bar on proposed rules that require lawyers to consider the interests of non-clients has been difficult in the past and will likely remain difficult in the future. ${ }^{168}$

The instrumental perspective is clearly insufficient to explain people's views about the legitimacy of authority and their behavioral compliance with the law. Citizens act as naive moral philosophers, evaluating authorities and their actions against abstract criteria of fairness. The instrumental conceptions of the person that have recently dominated discussions of legal issues are incomplete. Explanations based on the image of people as entirely rational beings who maximize utility are Id. insufficient to account for their behavior in social groups.

164. Id. at 166 .

165. Id. at 168 .

166. $I d$. at 178 . The study did not determine the origin of this general sense of obligation to obey the law but found it to have a strong relationship to the incidence of compliance with the law. Id. at 167-68. The author of the study concludes:

$[\mathrm{P}]$ eople's normative attitudes matter, influencing what they think and do. The image of the person resulting from these findings is one of a person whose attitudes and behavior are influenced to an important degree by social values about what is right and proper. This image differs strikingly from that of the self-interest models which dominate current thinking in law, psychology, political science, sociology, and organizational theory, and which need to be expanded.

A change in our image of the person also has practical implications. People are more responsive to normative judgments and appeals than is typically recognized by legal authorities. Id. at 178 .

167. Professor Daicoff's review of studies of lawyers' ethics led her to conclude that lawyers are generally likely to have the same level of moral development as others of the same educational attainment. See supra note 90.

168. During the drafting and approval process that resulted in the ABA's adoption of the Model Rules 
Achieving consensus within the bar that new rules restricting lawyers' customary zeal are right and proper presents a true test of the profession's will. Still, persistent bar efforts to confront the problem directly would be more valuable than continued exhortations to members to exercise greater professionalism while leaving the organization's professional rules largely promoting only the current default principle of zealous advocacy. If such a consensus for changes in the Model Rules cannot be reached in the ABA, perhaps greater success could be achieved in the bars and supreme courts of individual states. ${ }^{169}$

In assessing their potential success in changing lawyers' behavior, we must also keep in mind that even the successful enactment of new rules may not be sufficient to accomplish the task, as experience with such an effort in New Jersey suggests. In 1984 the New Jersey Supreme Court adopted a modified version of Model Rule 1.6(b) on client confidences. ${ }^{170}$ The ABA's rule at the time provided a limited exception to a lawyer's duty of confidentiality, permitting disclosure but not requiring it when the lawyer believed it reasonably necessary to prevent the client from committing a criminal act that the lawyer concluded was likely to result in imminent death or substantial bodily harm to another. ${ }^{171}$ However, the 1984 New Jersey rule

in 1983, a number of proposals by the Kutak Commission that would have reduced the zeal demanded of lawyers were rejected by the ABA's House of Delegates. Gaetke, supra note 113, at 69-71. Similarly, as noted above, the Ethics 2000 Commission's proposals to broaden permissible disclosures under Model Rule 1.6 were rejected by the House of Delegates in August 2001, only to be subsequently adopted in August 2003 after embarrassing public revelations regarding lawyers' behavior in several prominent corporate scandals. See supra text accompanying notes 144-48.

Some doubt whether a sufficient base of common values exists among lawyers to support any organized effort to improve their conduct. See, e.g., Robert F. Cochran, Jr., Professionalism in the Postmodern Age: Its Death, Attempts at Resuscitation, and Alternate Sources of Virtue, 14 Notre DAME J.L. EThics \& Pub. PoL'y 305, 306 (2000) ("Though Iwish the new professionalism well, I am not hopeful. In a postmodern age, there is little common moral ground to which we can appeal. I fear that the foundations for professionalism are gone. . . . In a postmodern age, there may be greater hope in encouraging lawyers to explore their own moral and religious traditions for lawyerly ideals." (footnote omitted)).

169. As noted above, the states have already shown an inclination to adopt rules that embrace a less zealous role for lawyers in the area of exceptions to the confidentiality expected of lawyers. See supra text accompanying note 152 . Whether the ABA's continued inaction in shifting the balance of the rules toward less zealous behavior may or should cause state supreme courts to strike out on their own is an interesting question, but one beyond the reach of this discussion.

170. N.J. Rules of Prof'L Conduct R. 1.6(b) (1984). For an excellent discussion of the background of this rule and of a study seeking to determine its effect on New Jersey lawyers, see Leslie C. Levin, Testing the Radical Experiment: A Study of Lawyer Response to Clients Who Intend to Harm Others, 47 RutGERs L. REV. 81 (1994).

171. Model Rules of Prof'L Conduct R. 1.6(b)(1) (1983). The ABA's 1983 approach in the 
mandates disclosure when the lawyer reasonably believes it necessary to prevent a client from "committing a criminal, illegal or fraudulent act that the lawyer reasonably believes is likely to result in death or substantial bodily harm or substantial injury to the financial interest or property of another."172 The rule directs that lawyers at times must be more concerned about the safety and even the financial interests of non-client third parties than they are about their clients' interests. It thus represents a perfect example of a rule designed to reduce the single-minded client loyalty that characterizes the current lawyer-client relationship in favor of a model that reflects more "professionalism," 173 as we have been using the term in this discussion. ${ }^{174}$

In a helpful article, Professor Leslie Levin reviewed the effectiveness of the 1984 New Jersey rule after the first eight years of its applicability. ${ }^{175}$ Among the 776 lawyers who responded to the study's survey, ${ }^{176} 67$ revealed that they had experiences in which they reasonably believed a client was going to engage in physical violence against an identifiable third person,,${ }^{177}$ and 190 indicated that they had reached a reasonable belief that a client was going to engage in a wrongful act that would substantially harm the financial interests

Model Rules adopted a discretionary approach to the issue of disclosure even in these serious circumstances, allowing lawyers to exercise their own sense of morality in deciding whether to disclose. See Levin, supra note 170, at 101. As noted above, a large number of states adopted variations of Model Rule 1.6(b) that broadened the discretion granted by the ABA's version or even made disclosure mandatory in some circumstances. See supra note 152. It should also be noted that the ABA subsequently amended its versions of Model Rule 1.6 to grant discretion to lawyers in making disclosures in other circumstances. See supra text accompanying notes 144-48.

172. N.J. Rules of PRof'L Conduct R. 1.6(b)(1) (1984). The rule reads:

(b) A lawyer shall reveal such information to the proper authorities, as soon as, and to the extent the lawyer reasonably believes necessary, to prevent the client:

(1) from committing a criminal, illegal or fraudu lent act that the lawyer reasonably believes is likely to result in death or substantial bodily harm or substantial injury to the financial interest or property of another....

Id.

173. The new rule was characterized as reflecting New Jersey's "high professional standards." Levin, supra note 170, at 95. Professor Levin observes that disclosures to protect the interests of non-client third parties are part of the lawyer's role as an officer of the court, which is another way to refer to the lawyer's primary obligation as being to the procedures and institutions of the law. Id. at 99 .

174. The New Jersey rule was adopted in part because of the bar's concerns about the falling public esteem of lawyers. Id. at 93.

175. Id. The New Jersey rule was adopted in 1984 , and the survey on which the article is based was conducted in September 1993. Id. at 107.

176. $I d$. at $110 \mathrm{n} .118$. The survey yielded a return of approximately $40 \%$. Id. at 110 .

177. $I d$. at 111-12. More than one-half of the surveys were directed to lawyers working in criminal defense and family law matters, two groups that might be expected at times to confront clients wanting to cause serious harm to the interests of others. Id. at 107-108. 
or property of non-client third persons, ${ }^{178}$ indicating that the problem is not an insignificant one. ${ }^{179}$ Commendably, almost all of these lawyers acted to try to dissuade their clients from the wrongdoing, ${ }^{180}$ and most of their clients ultimately did not commit the threatened actions. ${ }^{181}$ Because many of these lawyers likely never had reason to believe that disclosure was necessary to prevent the wrongful act, the actual set of lawyers who confronted the duty to act under the rule is much smaller. ${ }^{182}$ Among this group, Professor Levin notes that 12 lawyers who ultimately had the duty to disclose confidential information to prevent physical harm to others under the 1984 rule did so disclose, while 12 others did not. ${ }^{183}$ The disclosure rate was even lower among the lawyers who were required to disclose their clients' intentions to commit wrongful acts that would result only in harm to the financial or property interests of third persons. Only 8 lawyers in that situation made the required disclosures, while 84 lawyers who believed that such harm would occur reported that their clients ultimately did commit the wrongful act or may have done so. ${ }^{184}$ Arguably, therefore, many or perhaps all of these lawyers should have made the required disclosures.

Professor Levin found that for the lawyers who made the mandated disclosures, compliance with the rule was an important factor. ${ }^{185}$ Indeed, for the lawyers who disclosed their clients' intention to commit wrongful acts that would harm only the financial or property interests of another, such compliance was a more important factor than concern about the victims. ${ }^{186}$ According to Professor Levin, the new rule thus had "some impact" on

178. Id. at 112 .

179. Professor Levin also so concludes. Id. at 113.

180. Professor Levin reports that $92.4 \%$ of those facing client threats of physical violence and $97.8 \%$ of those confronting client threats of wrongful acts that would harm the financial or property interests of others discussed with their clients the impropriety of their threatened actions. Id. at $117 \& \mathrm{nn} .156 \& 162$. Only $20 \%$ of the former group and $12 \%$ of the latter, however, actually threatened to disclose the clients' intentions to others if they persisted. Id. at 117-18.

181. Id. at 119.

182. Acting under the rule, a lawyer could reach a reasonable belief that the client would commit the act but then conclude that disclosure was not necessary to prevent it. This might reflect the success of counseling against the act or other factors. Id. at 128 \& nn.210-11.

183. Id. at 129 .

184. $I d$.

185. Id. at 131 .

186. Id. Professor Levin concludes that these lawyers were more concerned about their own interests in avoiding violation of the rule. $I d$. at 132. Lawyers making disclosures regarding their clients' physical safety, on the other hand, listed concern about the victims as more important than rule compliance. Id. at 131. Professor Levin sees this as reflecting "moral concerns." Id. at 132. 
lawyers deciding to disclose their clients' intentions, although it may not have been the "primary reason" for doing so. ${ }^{187}$

In exploring possible reasons for the failure of other lawyers to comply with the rule, Professor Levin notes the countervailing pressures of the "strong bar ethic concerning protection of client confidences." 188 In other words, the concepts and culture of client loyalty and zealous advocacy underlying the lawyer-client relationship were still operating for some lawyers even in the face of a clear, contrary directive embodied in a rule. ${ }^{189}$

Caution is thus warranted in assuming a mere change in rules will result in compliance and more ethical behavior by lawyers. ${ }^{190}$ It must also be noted that the reluctance of lawyers to abandon strongly held views regarding the lawyer-client relationship, even in the face of clear rules to the contrary, justifies similar caution as to the likely success of further appeals to lawyers' consciences or grants of broader discretion regarding difficult professional issues.

187. Id. at 132 . This should not be too surprising. Hopefully many or most lawyers would act to protect innocent victims for reasons other than mere compliance with professional rules. Still, mandatory rules appear to play a role in causing lawyers to act in certain ways when confronting ethical issues. Professor Zacharias, for example, has noted the importance of rule compliance in matters of confidentiality, citing survey results showing that the rules caused lawyers not to disclose confidential information when they otherwise wished to do so. Fred C. Zacharias, Rethinking Confidentiality, 74 IowA L. Rev. 351, 381-82 (1989).

188. Levin, supra note 170, at 130. Professor Levin also discusses the level of support for New Jersey's disclosure rule among lawyers surveyed. Id. at 132-36. The higher general agreement with the disclosure requirement in cases of threatened physical harm and the lower level of agreement with mandatory disclosure for cases of potential financial harm reflect the levels of compliance with each requirement. $I d$. at 134-35. Still, a majority of surveyed lawyers supported both types of disclosure requirements. $I d$. at 134. Professor Levin's findings in dicate the difficulty of generating a consensus within the bar for more "professional" rules, making compliance with the law less likely. See supra text accompanying notes $168-69$.

189. This underscores the importance of establishing a consensus for the establishment of the new rule running contrary to the norms of zealous advocacy and client loyalty. Professor Levin so concludes as to the New Jersey rule. Levin, supra note 170, at 148. There was better compliance with the rule requiring disclosures to prevent physical harm to others than with the rule requiring disclosures for pending financial and property harm to others, reflecting the relative support for the two requirements within the bar. Id. at $134-35$.

190. Professor Zacharias notes that the assumption "that mere adoption of a professional rule will cause lawyers, at least most lawyers, to follow them" is one of the "delusions about lawyers." Zacharias, Future Structure, supra note 90, at 844, 847. 


\section{B. The Need for Enforcement}

While mere enactment of rules might yield limited results in changing lawyers' behavior, there is reason to believe that rules will have greater impact if there is an apparent effort to enforce them. ${ }^{191}$ If professionalism is a concern, and the profession regularly declares that it is, then the bar must not only demand professional conduct in its own rules, it must also be willing to enforce those rules through disciplinary proceedings against lawyers who are unwilling to comply. ${ }^{192}$

Perhaps the best evidence of what enforcement can do to alter lawyers' behavior comes not from a change in ethical rules but from a court's prominent decision to enforce more rigorously a rule already enacted. The case that best illustrates this is In re Himmel ${ }^{193}$ in the state of Illinois. There the state supreme court suspended a lawyer for one year for failing to report the ethical violation of another lawyer, ${ }^{194}$ even though it was to the client's advantage to have the lawyer refuse to do so, ${ }^{195}$ and even though the client requested the lawyer not to do so. ${ }^{196}$ The obligation of lawyers to report the ethical violations of other lawyers, though embraced to one degree or another since the adoption of the Model Code of Professional Responsibility in $1969,{ }^{197}$ has been said to be widely ignored by lawyers and rarely enforced by

191. Historically, the organized bar has been subject to criticism for lack of enforcement of rules of professional conduct, although recent efforts have improved in this regard. Professor Wolfram notes that "[w] hile lawyer discipline was once scandalously under enforced and is still criticized by many as lax, there is no doubt that its incidence has increased significantly in the past thirty years." Wolfram, Legalization of Legal Ethics I, supra note 113, at 470 (citation omitted).

192. Professor Zacharias observes that "[f]ora code provision to have measurable, reinforcing impact, it must appear to be realistic; it will have no coercive influence when its targets consider the provision unenforceable or unlikely to be enforced." Zacharias, Specificity, supra note 54, at 251-52 (citations omitted). He also elsewhere concludes, however, that "one could safely hazard the assertion that few rules truly are enforced in a way that makes lawyers fear discipline for violating them." Zacharias, Future Structure, supra note 90, at 862 (citation omitted).

193. 533 N.E.2d 790 (Ill. 1989).

194. Id. at 796.

195. Id. at 791 (discussing a situation where respondent lawyer drafted an agreement in settlement of a malpractice action, calling for payment of $\$ 75,000$ to the Plaintiff client upon the condition that no criminal, civil, or professional complaint were filed against the defendant lawyer).

196. Id. at 792-94.

197. The ABA's 1969 Model Code, applicable in the state of Illinois at the time the Himmel case arose, required lawyers to report unprivileged knowledge of another lawyer's violation of any Disciplinary Rule. Model Code of Prof'l Responsibility DR 1-103 (1980). The ABA's Model Rules, however, restricted this obligation only to more serious violations (those instances in which a lawyer had knowledge, from information not covered by Model Rule 1.6, "that another lawyer has committed a violation of the Rules of Professional Conduct that raises a substantial question as to that lawyer's honesty, trustworthiness 
disciplinary authorities. ${ }^{198}$ The clear statement by the Illinois Supreme Court through the suspension of the respondent lawyer in Himmel, however, had an immediate impact on the behavior of lawyers in Illinois, causing a wave of reports of lawyers' misconduct. ${ }^{199}$

What can be learned from the combined experiences in New Jersey and Illinois is that merely changing rules applicable to lawyers in the representation of clients may not be enough to affect the established behavior of lawyers, but rigorous enforcement of those new rules should help to obtain that effect. ${ }^{200}$ Therefore, in addition to accomplishing the difficult task of

or fitness as a lawyer in other respects"). Model Rules of Prof'L Conduct R. 8.3(a) (2003).

198. Zacharias, Future Structure, supra note 90, at 848.

199. It has been reported that the Illinois Attorney Registration and Disciplinary Commission received 331 lawyer complaints about other lawyers' misconduct during the five month period following the decision in In re Himmel. Paul Marcotte, The Duty to Inform, A.B.A. J., May 1989, at 17, 17. There is anecdotal evidence of similar effect. At a conference discussing the legality and ethics of lawyers over-billing their clients, for example, a representative of the Illinois Attorney Registration and Disciplinary Commission stated that In re Himmel had a significant effect on lawyers practicing in that state and indicated that such billing practices now commonly result in law firms reporting such misconduct by one of its own lawyers. Conference Report, 24th National Conference on Professional Responsibility, 14 ABA/BNA LAW. Manual Prof. Conduct: Current Reports 262, 272 (1998) (citing remarks by James Grogan concerning law firm billing practices). It has also been noted that, while lawyer reporting of other lawyers' misconduct to the bar has increased, discipline of lawyers for failing to do so has not. Reporting Misconduct, 101 ABA/BNA Law. Manual Prof. Conduct 201, 203 (2004). This perhaps underscores how a single, prominent case of enforcement can alter lawyers' behavior relative to an existing professional rule, despite a lack of regular, on-going enforcement efforts.

The Code provision enforced by the Illinois Supreme Court in In re Himmel was subsequently changed by that court's adoption of the state's version of the ABA Model Rules. Under its version of Model Rule 8.3, lawyers are required to report non-confidential knowledge only of another lawyer's criminal acts reflecting adversely on that lawyer's "honesty, trustworthiness or fitness as a lawyer in other respects" or conduct "involving dishonesty, fraud, deceit or misrepresentation.” ILL. RULES OF Prof'L Conduct R. 8.3(a), 8.4(a)(3)-(4) (1990). Lawyers must disclose other non-confidential information only upon request by an authority empowered to investigate lawyers. See id. R. 8.3(c). This is a more restricted approach to reporting lawyer misconduct than under the ABA's version of Model Rule 8.3, which has been adopted by most states. That rule requires a lawyer to report non-confidential knowledge of another lawyer's violation of any other rule that "raises a substantial question as to that lawyer's honesty, trustworthiness or fitness as a lawyer in other respects." Model Rules of Prof'L Conduct R. 8.3(a) (2003). Thus, with the adoption of its version of the reporting rule, Illinois could be said to have moved from being the most aggressive state in its treatment of the duty of lawyers to report other lawyers' misconduct under Himmel to one of the more lenient. The most lenient states, however, are California and Kentucky, which have no requirement that lawyers report misconduct of other lawyers, no matter how egregious those violations may be. 101 ABA/BNA Law. Manual Prof. Conduct 201 (2004).

200. This conclusion would seem to be consistent with developments in other areas of law applicable to the public generally. For example, over the past several years the public's behavior has been changed by clear rules and consistent enforcement in regard to driving while intoxicated, as well as to occupants wearing seatbelts in motor vehicles. S. Patricia Chou et al., Twelve-month Prevalence and Changes in Driving after Drinking: United States, 1991-1992 and 2001-2002, 80 Drug ANd Alcohol DePENDEnce 
adopting rules that are both moral and legitimate, ${ }^{201}$ we must expect that more demanding rules would have their impact on the profession over time rather than immediately. The enactment of such rules alone might alter the behavior of the most informed, conscientious, and rules-oriented lawyers. Other members of the profession might not respond until it was clear that the rules would be enforced, most likely through publicity regarding cases sanctioning lawyers for their disobedience. ${ }^{202}$ Unfortunately, some lawyers will never follow the rules, whether they are revised or not. For these lawyers, only suspension or disbarment will protect the public and the profession from their misconduct. ${ }^{203}$

While there should be little doubt that the mere announcement of new rules will have only limited immediate effect in shifting the profession from its allegiance to clients dictated by the lawyer-client relationship, ${ }^{204}$ there is hope for improvement through enforcement of better rules. Even if the impact on the behavior of lawyers through the enactment and enforcement of these new rules is limited, there are additional reasons for adopting rules that reduce the zeal demanded of lawyers by the present ethical rules.

223, 227 (2005), available at http://dx.doi.org (citation doi:10.1016/j.drugalcdep.2005.03.013) (recognizing reductions in drinking-driving occurrences over the past three decades); Survey Finds Safety Belt Use in U.S., 50 Prof. SAFety 16, 16 (2005). On the other hand, the lack of regular enforcement has been cited as a reason for the failure of regulatory efforts to ban the use of hand-held cellular phones while driving. Amanda Milkovits, Study to Probe Whether Using Cell Phones Drives Motorists to Distraction, Providence J., June 13, 2005; William Glanz, Drivers Must Keep Hands off of Cell Phones, Wash. Times, June 30, 2004, at A01; Jimmy Greenfield, Tough Cell, CHI. TriB., Dec. 22, 2005, at 6.

201. For further discussion, see supra text accompanying notes 168-69.

202. Professor Levin concludes that lack of enforcement was one reason for the lack of greater compliance with the New Jersey rule on mandatory disclosures to prevent harm to others. Levin, supra note 170 , at 148-49. She also notes that a lack of enforcement of a rule, particularly when it is not supported by a consensus of the bar, may have a broader effect, engendering cynicism and disrespect for other ethical rules. Id. at 149. Bar efforts to enforce a range of rules, on the other hand, might result in broader compliance by lawyers. Zacharias, Future Structure, supra note 90, at 870 .

203. It would seem that, as to these lawyers, the professionalism response and the deliberative approach are particularly unlikely to be successful and that a more rigorous set of rules and enhanced enforcement would most likely serve this cleansing function. In this regard, Professor Zacharias observes that the failure of some lawyers to follow rules means that "the future of legal regulation probably will include a greater focus on disciplinary issues and that the recent trend toward 'legalization' of the codes will continue." Zacharias, Future Structure, supra note 90, at 849.

204. Professor Loder has this difficulty in mind in asserting that "the tightest imaginable code could not erase moral imperfection in lawyers any more than the Ten Commandments could eliminate sin in religious believers.” Loder, supra note 56, at 330. 


\section{The Broader Role of Rules}

Ethical rules define the role that lawyers are to play in performing their duties within the judicial system ${ }^{205}$ and in accomplishing transactions for their clients. They do this by setting forth the profession's expectations as to lawyers' conduct generally and, more specifically, in a range of difficult situations. In addition to the guidance and control they offer lawyers in the practice of their profession, ${ }^{206}$ rules serve other important functions that should not be overlooked in consideration of how best to respond to the perception that lawyers' ethical conduct is in decline.

Among the additional, broad functions they serve, the ethical rules are the organized bar's clearest public statement of its true values. ${ }^{207}$ If the rules largely embrace the zealous advocate model of lawyering, they represent to the public that this is the primary value of the bar. If the rules do not insist on lawyers subordinating the interests of their clients to the procedures and institutions of the law in any significant way, it is hard to insist that this really is a value of the bar, let alone "the central moral tradition of lawyering." Indeed, if, as has been asserted, "the lawyer's primary obligation [is] to the procedures and institutions of the law" 208 rather than to the interests of her client, it is strange that this assertion is not made anywhere in the profession's present statement of its rules of ethics. What is the public to conclude from the absence of such a statement, especially in light of clear rules demanding

205. Zacharias, Specificity, supra note 54, at 231. In discussing the role of rules in the adversary system, Professor Lawry also notes that it is part of "the lawyer's fundamental obligations to the legal system, to observe its procedural rules and ensure that the client observes them too. This obligation is just as important to the proper functioning of the judicial system, as it is for the lawyer to be the client's champion. ... If lawyers are to be true to their fundamental task as advocates, scrupulous observance of the rules is of vital importance." Lawry, supra note 29, at 342 . He goes on to state that "if lawyers were more committed to their primary obligation of playing by the rules, many of the major problems of distortion [of the processes, procedures and institutions of the judicial process] would be eliminated." Id. at 344 .

206. Professor Loder observes that "[f]or the busy practitioner, a code and the substantive law covering professional conduct may be the only significant practical rub between habit and self-reflection." Loder, supra note 56, at 329. Professor Lawry also speaks to the value of rules in stating that "until we say clearly what it is we expect from the various officers of the law [including lawyers], we invite more chaos. Although expectations do not always lead to action, they are a good place to start." Lawry, supra note 29, at 326 .

207. Professor Loder so notes this role of rules when she states that "[c]odes currently offer the primary and most comprehensive statements of a lawyer's obligation to the public." Loder, supra note 56, at 329. She further notes that "[ $t]$ he public and lawyers alike deserve a clearer picture of the acceptable lawyer." Id. at 331.

208. Cramton, supra note 14, at 8 . For further discussion, see supra text accompanying notes 28-32. 
competent, diligent, and zealous representation of clients? Put simply, the profession's values are those principles it is willing to incorporate in its professional rules. It is thus in the ethical rules that the public can perceive whether the profession is sincere in its frequent pronouncements that lawyers are officers of the legal system rather than mere zealous advocates. ${ }^{209}$

Beyond being public statements of the bar's values, the rules also define for those seeking legal services the legitimate expectations they might have as to their lawyers' behavior. ${ }^{210}$ The rules already direct lawyers to clarify for their clients the relevant limitations imposed by the rules when they find that their clients expect behavior that is not allowed. ${ }^{211}$ Greater restrictions on lawyers' zeal through more demanding, system-oriented rules would cause lawyers to so inform their clients, ${ }^{212}$ thus reducing the demands that the clients might place upon them to be more zealous. ${ }^{213}$ To the extent that the rules

209. While most members of the public will never have occasion to read any of the rules to test those assertions, media coverage of the bar's efforts to change the rules calls the attention of the public to the direction of that change.

210. One publication designed for entering law students notes:

If no particular set of values could be ascribed to lawyers . . . [n]either lawyers nor non-lawyers would be able to predict the kind of interaction they would have with each other in professional contexts. . . . This extreme result has been avoided, however, by introduction to the Bar's selfgenerated and self-imposed codes of "professional ethics." ... This in turn produces some level of predictability in one's interaction with lawyers: the public and other lawyers can now expect lawyers to do or not do some things in certain circumstances.

Timothy P. Terrell \& James H. Wildman, Rethinking Professionalism, in Professionalism Primer, supra note 18, at 19. Professor Haskell sees this connection when arguing for a prohibition on lawyers lying even about immaterial facts in negotiations, a practice currently authorized by Model Rule 4.1. He writes: "Clients may, if they are so inclined, engage in such practices on a regular basis. When they hire lawyers to represent them, they should expect that the standard of behavior is different. Lying in negotiations is morally wrong; there is no consideration that justifies its use." HASKELL, supra note 101, at 71.

211. The ABA's current Model Rules provide that a lawyer shall "consult with the client about any relevant limitation on the lawyer's conduct when the lawyer knows that the client expects assistance not permitted by the Rules of Professional Conduct or other law." Model Rules of Prof'L Conduct R. 1.4(a)(5) (2003). The ABA also incorporates the same concept in Comment [13] to Model Rule 1.2. The substance of this provision was previously found in Rule 1.2(e) of the original 1983 version of the Model Rules.

212. There is some doubt about how frequently lawyers fully advise their clients on the limits of and exceptions to the duty of confidentiality, resulting in concern that clients generally have an overly expansive view of the protection offered by that duty. For a discussion of some empirical studies exploring this issue, see Levin, supra note 170, at 103-06.

213. In discussing the arguments in favor of the 1984 New Jersey rule on disclosing confidential information, discussed in text accompanying notes 170-89 supra, Professor Levin observes that the rule will alter clients' expectations of their lawyers as willing to "do anything for them," as one might expect of a loyal agent. Levin, supra note 170, at 100.

While better rules might alter clients' expectations regarding their lawyer's professional behavior, Professor Zacharias cautions us that new rules will not necessarily result in clients having greater trust in 
directed lawyers to curb their zeal, over time the expectations of clients as to such behavior would be eased as well.

Perhaps most importantly, the rules also serve as the norms of the profession presented to the thousands of law students seeking admission to the bar each year. The ABA recognizes the significance of this function by requiring some form of coverage of the rules of ethics in the academic program of all accredited law schools. ${ }^{214}$ Thus the bar's ethical rules are instrumental in forming the substantive content of most professional responsibility courses throughout the country. While the emphasis of instructors varies, ${ }^{215}$ through these courses law students learn and apply the ABA's current body of ethical rules, and ultimately they are tested on their knowledge of the rules during the bar examination. By this process, they learn the extent to which the profession's rules expect lawyers to subordinate their clients' interests to those of the public or the judicial system. ${ }^{216}$ The content of the rules thus becomes a basis of knowledge upon which the students will later draw when confronted with ethical issues in practice. ${ }^{217}$ That content also may ultimately become a part of the professional value system ${ }^{218}$ upon

their lawyers. Zacharias, Future Structure, supra note 90, at 849-51.

214. ABA Standards for Approval of Law Schools and Interpretations, Standard 302(a)(5) (2005-2006).

215. Some criticize the typical course in professional responsibility's focus on the content of the rules as teaching "legal ethics without the ethics" and leaving "future practitioners without the foundations for reflective judgment." Deborah L. Rhode, If Integrity Is the Answer, What Is the Question?, 72 FordHAM L. Rev. 333, 340 (2003).

216. Professor Zacharias observes that "[1]aw students taking the basic professional responsibility course inevitably assume that professional codes are the primary constraint on lawyer conduct." Zacharias, Future Structure, supra note 90, at 861. He also notes, however, that this is not an accurate impression because "[i]n reality, of course, professional discipline is not all it is cracked up to be." Id.

217. Dean Burnele Powell focuses on the importance of lawyers' knowledge of the profession's standards of conduct in making them more ethical lawyers. Burnele V. Powell, The Limits of Integrity or Why Cabinets Have Locks, 72 Fordham L. Rev. 311, 313 (2003). He notes:

[L]awyers are ethical, competent, diligent, professional, etc., to the extent that they know and are committed to the standards of conduct of the legal profession. Conversely, they are lacking in such qualities to the extent that it can be demonstrated that they are without a sufficient knowledge base to be held accountable.

Id. at 314 . He describes an "ethical lawyer" as one "who knows the standards of the legal profession and has affirmatively pledged to conform to them." Id. at 313 .

218. There is some evidence that lawyers themselves see their legal education in professional responsibility as establishing their sensitivity to issues of legal ethics. Bryant G. Garth \& Joanne Martin, Law Schools and the Construction of Competence, tbls. 4-8 (Am. Bar Found., Working Paper No. 9212, 1992); see also Daicoff, supra note 4, at 1422-23 ("There is evidence that some law school courses can promote a higher stage of moral development, but whether a higher stage of moral development would result in moral behavior is unclear."); id. at 1423 (Law students "who do not resemble the lawyer 'norm' in terms of values and decision-making approaches appear to be changed by law school to fit the norm 
which graduates will rely as they continue their careers in the law. ${ }^{219}$ This suggests that a shift in attitudes about professionalism may take time, as recent graduates who have been trained in the new rules become a larger percentage of the practicing bar. ${ }^{220}$

The rules of legal ethics are important as public statements of the profession's values, determinants of clients' legitimate expectations, and the initial foundation of what new lawyers know about the proper practice of law. In these and other ways, ${ }^{221}$ the legal profession's rules of legal ethics play a larger role than merely providing black letter disciplinary law for lawyers engaged in practice. Even public or professional skepticism about their effect in changing current lawyers' behavior, therefore, should not dissuade the profession from attempting to demand more professional behavior from its members through new rules.

\section{A Place to Start}

Where would the organized bar start if it were to draft rules directing lawyers to act less zealously on behalf of their clients and more consistently

... "). Interestingly, Professor Levin's study of the effects of the 1984 New Jersey version of Model Rule 1.6 found greater support for mand atory disclosure to prevent physical harm among lawyers admitted after the adoption of that rule than among older lawyers. Levin, supra note 170, at $142 \mathrm{n} .277$. This may suggest some lingering professionalism effect from professional responsibility education among those most recently graduated from law school.

219. Of course there are other components of that value system, such as the culture of the profession, the demands of the practice setting, and the individual lawyer's personal and religious values. Professor Levin notes the influential impact of the prevailing customs within the practicing bar on lawyers' willingness to obey specific ethical rules. Levin, supra note 170, at $143 \mathrm{n} .278$. While studies on the effect of law school on law students' moral reasoning have had varied results, some have concluded that students' sensitivity to ethical issues rises during law school and then falls during law practice. Daicoff, supra note 4, at 1398 .

220. Professor Levin reports that even after nine years following the adoption of the New Jersey rule mandating disclosures of confidential information to prevent certain wrongful acts by clients that will harm others, the general notion of strict confidentiality "remained firmly rooted in the bar." Levin, supra note 170 , at 134. For the most part, however, the bar that was being surveyed in that study had received their ethical training, if they had received any such training at all, on rules that pre-dated the $1984 \mathrm{New}$ Jersey rule. She also points out that once a lawyer is admitted to the bar, she may never have occasion to become familiar with a new professional rule unless it covers an issue that arises in practice. Id. at $147 \mathrm{n} .296$. One might speculate that law students educated in the new rule would have different attitudes about the level of confidentiality a lawyer owes a client. Interestingly, as noted at supra note 218 , her survey showed that "newer lawyers more strongly supported the mandatory disclosure rule to prevent bodily harm and to prevent illegal acts that would result in environmental harm." Id. at 142 n.277.

221. Professor Zacharias lists other tasks professional rules work to fulfill. Zacharias, Future Structure, supra note 90 , at 862. 
with the supposed "central moral tradition of lawyering," that lawyers' primary obligation is to the procedures and institutions of the law? ${ }^{222}$ As just noted, that value, if indeed it is a value of the profession, is not significantly reflected in the current rules governing the conduct of those in the profession, is not part of the expectations clients have of their lawyers, and is not a component of the professional knowledge base or value structure imparted to aspiring lawyers through the rules. What is worse, the existing rules generally embrace just the opposite contending professional values of rigorous loyalty to clients and warm zeal in pursuing their interests. ${ }^{223}$

An attempt to ameliorate the zeal demanded of lawyers, undoubtedly limited to civil matters, ${ }^{224}$ would likely require a substantial re-writing of the

222. As a cautionary note, Professor Lawry observes that "[n]o code or treatise has completely captured that tradition. It is doubtful any will; for like all traditions it is rich in stories and tales, complex in meaning and ambiguity, constantly on the move, changing, rising again like a phoenix from the ashes of our greed and compromise and necessity." Lawry, supra note 29, at 311. Even if the tradition cannot be fully captured in rules, it would seem helpful to have the rules reflect and support it.

223. Referring to the lawyers' conduct in responding to their clients' fraudulent practices in the notorious OPM Leasing case, Professor Lawry concludes that the "problem resulted from a ten sion between the relevant provisions of the Code and the obsessive client-centered approach to the Code and to the vocation of lawyering." Id. at 332. He notes that in 1974 the ABA amended the applicable 1969 Model Code by prohibiting the lawyer from disclosing client fraud, reversing the provision's original position directing such disclosure if the client failed to rectify the past fraud. Id. at 332-33. It would seem, therefore, that the OPM lawyers acted appropriately in failing to disclose the client's past fraud. Indeed, such a disclosure would have been a violation of the amended provision. Curiously, Professor Lawry concludes that what the lawyers did in failing to disclose the fraud "was to operate on the basis of a narrow, legalistic reading of the Code in order to avoid the painful reality of dealing with systemic abuse." Id. at 333. It would seem, however, that the ABA had deliberately chosen to overturn an ethical rule that protected non-clients from harm, replacing it with a pro-client provision. Furthermore, the state's highest court had decided to adopt the ABA's amendment, making it the law binding on New York lawyers. Id. at 332. Reading the new provision to conclude that the client's past fraud was not to be disclosed would appear to be neither a "narrow" nor "legalistic" approach. In not disclosing their client's past fraud, the lawyers simply did what the amended rule directed them to do.

224. In addressing pro-client efforts by lawyers, Professor Lawry makes a distinction between the conduct of lawyers defending those accused of crimes and of lawyers representing clients who may be engaged in fraud. He notes:

What was done to help the "guilty" criminal defendant is no more than what that defendant was entitled by law to have done for him. It is exactly the reverse in the fraud case. Here, if the lawyer knows what is happening, he or she must refuse to assist and counsel the client away from lawbreaking or fraud.... [T] he counseling function is the lawyer's primary function, and to counsel a client against lawbreaking and fraud is one of the lawyer's chief responsibilities as counselor."

$I d$. at 335. Professor Lawry is exactly right in this analysis. The rules make the distinction clear as well. Model Rule 3.1 permits a lawyer to represent a criminal defendant vigorously despite the lawyer's knowledge as to the client's guilt. See Model Rules of Prof'l Conduct R. 3.1 (2003). Model Rule 1.2(d), on the other hand, prohibits a lawyer from counseling or assisting a client "in conduct the lawyer knows is criminal or fraudulent." Id. R. 1.2(d). It would seem that these rules successfully incorporate a fundamental distinction in the profession's standards and the public's expectations regarding lawyers' 
current Model Rules, if not by the ABA, then by individual states desiring to undertake such an effort. This would be a daunting and controversial task, ${ }^{225}$ the full range of which is certainly beyond the scope of this discussion. As a starting point, however, a few changes to the rules would constitute an important start in that direction for the bar and would do much to convey to lawyers and the public alike the profession's intended shift in priorities.

If the bar were to undertake this effort it would be most significant for it to state clearly in a rule, ${ }^{226}$ preferably the first,${ }^{227}$ that the primary obligation of the profession is to the procedures and institutions of the law. Currently, the Model Rules contain no such statement in a rule, a comment, or the preamble, a remarkable oversight if indeed this is the "central moral tradition of lawyering." The prominent statement of the concept as the default position of the profession would set the tone for the rest of the rules. ${ }^{228}$ It could also be made clear in the rule or its comments that in the absence of specific rules to the contrary, this rule is to guide lawyers in their ethical decision-making. If enforcement of that general provision were pursued by the bar, case law

behavior.

225. As noted above, recent history has shown this to be true in regard to the proposals of the Kutak Commission and the Ethics 2000 Commission. See supra note 168.

226. This could instead be stated in the preamble to the rules. The first sentence of the Preamble to the Model Rules currently reads: "A lawyer, as a member of the legal profession, is a representative of clients, an officer of the legal system and a public citizen having special responsibility for the quality of justice.” Model Rules of Prof'L Conduct Preamble (2003). While this statement might be read to include the sort of leavening of the zealous advocate role that many seek, it does not offer a prioritization of the various roles. Thus, if the duty of the lawyer to the legal system or to the quality of justice is to prevail over the lawyer's duty to the client, the statement should make this clear. As it stands, the balanced view of the preamble statement is overtaken by the rules themselves, which demand competence, diligence, and loyalty in the representation of clients. It could also be noted that to relegate such a provision to the preamble is to draw into question its importance compared to the values stated expressly in the rules themselves.

227. For example, this could be contained in a new Model Rule 1.1, entitled "The Lawyer's Primary Duty," stating, "A lawyer's primary obligation is to the procedures and institutions of the law." This new rule would displace the current Model Rule 1.1, entitled "Competence." That rule could then be amended to provide that a "lawyer shall provide competent representation to a client, consistent with the lawyer's primary obligation under Rule 1.1." Similar specific amendments could be made to the rest of the rules where the ABA considered it important to specify that the duties stated were to be subordinate to the lawyer's "primary duty." The same result could be accomplished through a comment indicating the blanket dominance of the "primary duty" except where specified otherwise. Through these amendments, the rules would clarify the priorities of the bar's values.

228. It would, of course, be imperative to clarify in the rule or a comment how this primary obligation meshes with the role of the defense lawyer in criminal cases. It should not be difficult for the bar to state how loyal, zealous representation of a criminal defendant is a fundamental part of the defendant's constitutional rights and how this sort of representation is consistent with the lawyer's duty to the "procedures and institutions of the law." 
would develop over time to give more meaning and direction to its broad language.

Second, the bar could amend Model Rule 1.2, entitled "Scope of Representation and Allocation of Authority Between Client and Lawyer," to reflect the newly declared primary obligation of lawyers to the procedures and the institutions of the law. The current version of Model Rule 1.2 directs lawyers not to "counsel a client to engage, or assist a client, in conduct that the lawyer knows is criminal or fraudulent." 229 The rule currently fails to direct the lawyer to refuse assistance to a client when to do so would be contrary to the lawyer's primary obligation to the procedures and the institutions of the law. ${ }^{230}$ If that is the lawyer's primary obligation, this would seem to be an important place to make it clear that clients' interests are to yield to it.

Third, if lawyers are to be directed to be particularly responsible for justice, it would seem imperative that Model Rule 1.6 on confidentiality needs to be changed. It must be recognized that at some point lawyers have a duty to reveal confidences when necessary to prevent serious personal or financial harm to others, ${ }^{231}$ as does New Jersey's 1984 version of the rule. ${ }^{232}$ This battle has been fought before in the ABA. ${ }^{233}$ Even as amended in 2003 after the

229. Model Rules of Prof'L Conduct R. 1.2(d) (2003). The rule also makes clear that a lawyer's representation of a client "does not constitute an endorsement of the client's political, economic, social or moral views or activities." Id. R. 1.2(b). One possible change to the rule might be to alter this provision, thus reducing the influence of role-differentiated morality on the behavior of lawyers. This change, though interesting enough to mention, is beyond the scope of this discussion.

230. Although reflecting the current rules' preference for zealous advocacy, Model Rule 3.2, pertaining to expediting litigation, employs this technique of clarifying priorities. That rule provides that "[a] lawyer shall make reasonable efforts to expedite litigation consistent with the interests of the client." Id. R. 3.2. This wording expressly subordinates the lawyer's duty to expedite litigation to the best interests of the client. Here the ABA has made its value preference explicit. Of course, if the lawyer's first duty is to the procedures and institutions of the law, the ranking of priorities of these rules would require an amendment to reflect it, as indicated supra note 227.

231. Professor Lawry points to the ABA's adoption of the 1983 Model Rules provision on confidentiality as indicative of that organization's shift from broader protection of non-clients toward a more zealous pro-client position. Lawry, supra note 29, at 333-34. Interestingly, however, he finds the Kutak Commission's initial proposal to allow lawyers to disclose confidential information to prevent or rectify "wrongful" acts by a client as being "too idealistic in content." Id. He prefers the later proposed language that permitted lawyers to make such disclosures "to rectify the consequences of a client's criminal or fraudulent act in the commission of which the lawyer's services had been used." Id. at 334. Even that language was subsequently deleted by the ABA in adopting the original 1983 version of Model Rule 1.6. This void was addressed 20 years later in the 2003 amendments of Model Rule 1.6. See supra text accompanying notes 144-48.

232. For this discussion, see supra text accompanying notes 170-89. Professor Levin notes that in addition to New Jersey's broad disclosure rule, ten other states mandate disclosures to prevent physical harm to others. Levin, supra note 170 , at 95 n.55, 99.

233. For a brief discussion of the ABA's consideration of the Kutak Commission's proposals leading 
tragic revelations about Enron and other corporate fiascoes, ${ }^{234}$ the ABA rule only permits such disclosures, rather than mandating them, no matter the imminence or seriousness of the harm nor the degree of certainty that the lawyer has as to its likelihood. ${ }^{235}$ Since the bar has already determined that such disclosures are permissible, it is hard to imagine what argument could be made to conclude that disclosure should not be mandatory in sufficiently serious circumstances, at least if the lawyer's primary duty is to be to the procedures and institutions of the law. ${ }^{236}$

Fourth, if that is to be their primary obligation, lawyers should be expected to provide pro bono legal services to those in need. ${ }^{237}$ This concept

to the 1983 version of Model Rule 1.6, see Gaetke, supra note 113, at 69-70.

234. For discussion of these amendments, see supra text accompanying notes 144-48.

235. In referring to the 1983 Kutak Commission proposal for a similar discretionary treatment of disclosures of client fraud or crime, which were rejected by the ABA at the time, Professor Lawry declares that "[t]his kind of provision best exemplifies the [central moral] tradition [of lawyering]." Lawry, supra note 29 , at 334 . He goes on to note that with such a provision "[1] awyers" services may not be used to commit crimes or frauds; if they are, the client may not use the confidential relationship provided by the system to abuse the system further." Id. It would seem, however, that if a client is represented by a lawyer who chooses not to make the disclosure under the discretionary provision, that client is able to so use his lawyer's services. Only a mandatory disclosure provision would prohibit the client's abuse of the confidentiality offered by the lawyer-client relationship.

236. Although Professor Loder recognizes that even complex moral questions can be the subject of precise rules when necessary to protect the public, Loder, supra note 56, at 325, she also expresses doubt as to the propriety of a clearly defined duty to reveal confidential information to protect another from harm. She notes:

"Under what, if any, circumstances would my failure to prevent harm to another person, which I could prevent by revealing information about my client, be justified in terms of my prescribed advocate's role within our adversary system of justice?" Although it is easy to argue that the question needs to be answered with greater clarity and force, it is also easy to overlook the implications of imposing on all lawyers particular answers to such a complex question.

$I d$. at 322. I am not sure what Professor Loder may have in mind as "the implications" of such a requirement or what a better example of situations in which a rule is "necessary to protect the public" might be.

237. In discussing his view of the central moral tradition of lawyering, Professor Lawry emphasizes that "lawyers have a responsibility to help to make legal services available to all," Lawry, supra note 29 , at 361 , and "are bound by their calling to help in the effort to give complete access to our system of justice. This obligation is serious and fundamental." Id. He sees the pro bono obligation as "not a matter of charity. It is an obligation that comes with the license to practice law." Id. at 362 . He makes the point strongly:

It is clear that the central tradition requires lawyers to make representation available to all, particularly to the poor and unpopular. What must be emphasized is that these obligations are just that-obligations. Neither the individual nor the profession as a whole may ignore them.

$I d$. at 363. Still, Professor Lawry does not propose a rule incorporating that "obligation," despite his view as to the centrality of the duty's importance.

Professor Loder, on the other hand, seems to prefer that this topic continue to be covered by a "rule" that exhorts lawyers to engage in pro bono work but does not require it. Loder, supra note 56, at 335. This 
too has been debated in the past, but the ABA to date has been willing only to encourage lawyers to do so in Model Rule 6.1. Indications are that, despite that rule, the legal services needs of the poor are still not being met. While many arguments have been made against the imposition of a mandatory rule to direct lawyers to be charitable with their time and services, the bar's recognition of the profession's obligation to the procedures and institutions of the law would demand it. ${ }^{238}$

Fifth, it would seem imperative that, in order to reflect lawyers' primary duty to the procedures and institutions of the law, if that indeed is to be done, Model Rule 4.1(a) needs to be amended to eliminate the one rule that openly permits, and perhaps encourages, lawyers to lie. The rule itself directs lawyers not to make false statements of material fact to others, but the comment to the rule indicates that some statements are not considered "statements of material fact" 239 according to "generally accepted conventions in negotiation." ${ }^{240}$ Despite the comment's recognition of a certain degree of lying as being consistent with the game of negotiation, this position seems counter to any notion that lawyers' primary obligation is to the procedures and institutions of the law. ${ }^{241}$ A change in the comment to this rule would signal that, while other parties engaged in negotiations might be expected to use false statements, clients should know that when they choose to be represented by a lawyer in such matters, their representatives will not do so. ${ }^{242}$

is the approach currently taken by Model Rule 6.1.

238. Experience with another area of professional obligation suggests that such a rule would have an impact. The perceived ongoing problem of lawyer incompetence was addressed in the 1970s by rules requiring lawyers to participate in continuing legal education courses, a mandatory program now established in a clear majority of states. ABA/BNA Law. Manual Prof. Conduct, Manual No. 125, 21:3001-02. Of course, some lawyers previously maintained their professional currency willingly without such a mandatory rule, but the need for more widespread continuing education was apparent. This need was met by a rule directed to all lawyers, usually enforced by regular reporting as a legal condition to their renewal of licensing. $I d$. at 3003 . Some lawyers comply only begrudgingly with the mandatory rule on continuing legal education. The same would likely be true for a mandatory rule on pro bono services. Presumably, most lawyers would follow the rule and do a competent job of providing legal services to those in need. It would seem that a similar approach to the judicial system's need for pro bono legal services would not only be effective in securing more such service, it would also help fulfill the profession's primary obligation to the procedures and institutions of the law.

239. Model Rules of Prof'L Conduct R. 4.1(a) cmt. 2 (2003). For a discussion of this aspect of the rule, see supra text accompanying notes 100-03.

240. Model Rules of Prof'l Conduct R. 4.1(a) cmt. 2 (2003).

241. Others have noted that the existing rule also reflects a faulty preference for treating negotiations as based on the adversarial process model. Zacharias, Future Structure, supra note 90, at $857 \&$ n. 153 (citing other scholars so concluding).

242. See HASKELL, supra note 101, at 70-71. 
These five changes to the Model Rules would present a salutary public statement by the bar that its priorities are being brought in line with its rhetoric. A broader review and revision of the Model Rules would undoubtedly be needed to accomplish the real objective. ${ }^{243}$ Any immediate reduction of the disconnect between the present rules and public proclamations about the role of lawyers in our legal system would itself be an important achievement. The full impact of such changes on the conduct of lawyers, the ultimate objective of such an effort, of course, would take more time. $^{244}$

Even the most modest efforts along this line, however, are likely to prompt serious reservations and objections. Most obviously, there will be many who will point out that such new rules will be doomed to fail in the adoption process because the outcomes they require are not supported by a substantial portion of the bar. ${ }^{245}$ This is a real problem, and it has been faced before. To the extent the organized bar is unable to reach a consensus on

243. Even if the suggested rules were to be adopted, other rules more specific in application and probably more controversial in adoption would undoubtedly need to be considered in attempting to bring the rules more in line with the primary obligation of lawyers being to the procedures and institutions of the law. Model Rule 3.2 on expediting litigation would likely need amendment. See supra note 230. It would also seem likely that the bar would need to face the question of a lawyer impeaching a witness known by the lawyer to be telling the truth, alth ough the outcome of such consideration would be unclear. Model Rule 3.1 might need to be amended to broaden the definition of "frivolous" to reflect the lawyer's newly emphasized primary obligation. Cf. Model Rules of Prof'L Conduct R. 3.1 (2003). Some members of the profession might want to address the problem of declining civility in the rules. Throughout this consideration, it would be important to recognize that criminal defense matters would require special care and attention.

It might be noted that in 2002 the ABA adopted several rules to address specific ethical issues in a manner that reflected concerns about professionalism as that term has been used in this discussion. For example, Model Rule 4.4 was amended to deal with a lawyer mistakenly coming into possession of another party's documents, an issue that has been a common subject of state ethics opinions. Although it is a rule protective of clients' interests, the new Model Rule 1.8(j) on lawyers having sexual relationships with clients also reflects professionalism concerns about a recurring ethical issue. $17 \mathrm{ABA} / \mathrm{BNALAW}$. MANUAL Prof. Conduct: Current Reports 492, $493-94$ (2001).

There is debate on the level of specificity that is appropriate for addressing difficult ethical issues, and these issues would need to be addressed. Professor Levin, for example, argues that the 1985 New Jersey version of Model Rule 1.6 should have defined the lawyer's obligation to discuss the disclosure obligation with the client. Levin, supra note 170, at 145. Professor Zacharias, however, has noted the difficulties of being overly specific in rules governing difficult ethical issues. Zacharias, Specificity, supra note 54.

244. This aspect of changing lawyers' behavior is discussed supra notes 200-03, 214-20.

245. Professor Loder seems to fear this difficulty. "The assumption that problems of role morality can be alleviated by revising norms of advocacy conduct to emphasize [a greater duty to others or to the pursuit of truth] is therefore misplaced. That assumption presupposes a perfected system which provides standards of conduct compatible with the personal standards of all or most individual lawyers." Loder, supra note 56 , at 317. 
fundamentally important professional issues, no new rules will be adopted nor could they be successful. As noted above, ${ }^{246}$ the legitimacy of any new rules is critical to their eventual effectiveness in changing the behavior of lawyers. If no consensus could be reached on changes such as those suggested here, one can only conclude that lawyers' primary obligation is not to the procedures and institutions of the law, as many have professed. The current focus of the rules on zealous advocacy is certainly a defensible role for the bar, although one not consistent with public proclamations about lawyers having higher duties. Hopefully, the bar would choose in that event to abandon its frequent calls for greater professionalism among lawyers.

Some might also argue that the legal profession's disciplinary system should not try to legislate morality. The short response to that assertion is that I am not suggesting that the organized bar attempt to do so any more than it is currently doing. Through its adoption of the present Model Rules, the organized bar has taken a stand on a range of moral issues subsumed in the lawyer's duty of loyalty and zeal on behalf of the client. Nevertheless, one does not hear complaints currently that the bar should avoid legislating morality. The suggested amendments would simply be shifting to a different emphasis, one elevating concerns other than the client's interests as a priority. ${ }^{247}$

Professor Fred Zacharias takes this point in a slightly different direction. He argues that, because lawyers are merely human, the bar is unlikely to be successful at trying to use regulation to make lawyers "more upstanding than laypersons." ${ }^{248}$ More specifically to the present discussion, he believes that viewing lawyers as no better than others will "dispel the specific image that lawyers routinely sublimate their personal financial goals to the needs of the system." ${ }^{249}$ This observation is supportive of the approach suggested here. The profession's rules need to reflect that lawyers are morally no better, and likely no worse, than other members of society. Rather than expecting lawyers to be more "moral" than the rules demand, as the professionalism proponents urge, or leaving lawyers to follow their own moral compass, as the proponents of the deliberative response believe, the profession's rules ought to define the proper priority of values and, when possible, the proper course

246. See supra text accompanying notes 160-69.

247. An example of a rule reflecting such an emphasis is the ABA's 2002 amendment of Model Rule 4.4(b) on lawyers dealing with misdirected documents. Model Rules of Prof'L Conduct R. 4.4(b) (2002).

248. Zacharias, Humanization, supra note 54, at 10.

249. Id. at 24-25. 
for lawyers to take in certain situations. Professor Zacharias sees this approach as leading to better public acceptance of lawyers as well. ${ }^{250}$ While many of these duties will necessarily be left to the conscience of each lawyer, we should not assume lawyers will behave any better than other members of society without such rules or that they will be comparatively less willing to comply than others if those rules are enacted.

Some may maintain that lawyers are members of a learned, self-regulated profession and, therefore, do not need such guidance from their rules. This argument assumes that lawyers' present duty to the procedures and institutions of the law is implicit in the culture of the practice of law. However, other than public proclamations that this is the case, evidence of its existence is scant. Indeed, the current dissatisfaction with the behavior of lawyers, coming from inside and outside the bar, suggests that such principles are not operating. Even if lawyers are learned and self-regulated, the content of the law setting forth that regulation is as important to lawyers as it is to all members of society.

Critics of the changes suggested here might also note that there would be an insufficient amount of resources available to enforce these rules against unwilling lawyers. To this it might be noted that there probably are insufficient resources to enforce the present rules. ${ }^{251}$ Indeed, the argument has been made that professionalism would be better served currently by more rigorous enforcement of the present rules than by the constant urging of lawyers to be better persons and professionals. It should also be noted that the amount of resources devoted to enforcement, much like the revision of the rules themselves, is another measure of the will of the organized bar and a test of its sincerity in bringing the rules into alignment with its rhetoric about the profession.

250. Professor Zacharias notes:

The more the profession can accept publicly that many lawyers, like many laypersons, are flawed and that the provision of effective legal services depends less upon a superhuman breed of practitioner than upon practitioners who are trained in a particular system of rules, the more hope there is of lay acceptance of the profession's flaws.

$I d$. at 32. He also notes that recognizing that lawyers are subject to all human tendencies "can make the profession breathe easier in surrendering the need to develop superior beings within the profession." Id. at 33 .

251. See Zacharias, Specificity, supra note 54, at 254 (noting that "resource considerations often control enforcement policies"); Zacharias, Future Structure, supra note 90, at 862 (noting that "one could safely hazard the assertion that few rules truly are enforced in a way that makes lawyers fear discipline for violating them"). 
If the bar is to be effective in such an effort, it will need to recognize that mere changes in the rules, regardless of their content, will not be sufficient. To encourage compliance, the bar will need to convince the members of the profession that the rules are moral, right, and proper in order to secure the kind of consensus necessary to support the legitimacy of the rules. The bar will have to be willing to enforce the new rules when lawyers go astray and be patient as the new priorities take hold over time. If it is truly committed to making its public pronouncements about professionalism a reality, the organized bar must undertake this difficult task.

\section{CONCLuSion}

Dissatisfaction with the level of lawyers' professional behavior has led to two groups of proposals for improvement. Through public pronouncements regarding the higher professional duties of lawyers, the professionalism response urges lawyers to go beyond the present rules and to act with more concern about justice and interests other than those of their clients. On the other hand, the deliberative approach takes aim at the very use of legalistic rules to govern lawyers' behavior, asserting that they cause lawyers to construe duties narrowly and to disregard their own moral judgment in deciding how to act.

Both approaches are likely to be unsuccessful because they expect both too much and too little of lawyers. They expect too much in their assumption that lawyers will voluntarily discard the loyalty and zeal that now so thoroughly characterize the lawyer-client relationship. They expect too little in refraining from or arguing against the utilization of ethical rules to demand better behavior from lawyers.

If the bar is intent on changing the conduct of lawyers to adhere more closely to the commonly professed primary obligation of lawyers to the procedures and institutions of the law, it would be better to utilize rulemaking to restrain the current professional default principle of zealous advocacy. In addition to altering the current substantive content of the legal framework of the lawyer-client relationship, such an approach would provide a strong public statement as to the profession's re-ordering of values. Such rules would also adjust the expectations clients have in retaining lawyers to represent them. Finally, such rules would ultimately work to shift the value structure of lawyers.

Over time, rules that reflect a lawyer's primary duty to the procedures and institutions of the law would have a greater impact on behavior of those in the profession than either the continued urging of lawyers to be more professional 
or the grant of broader discretion in ethical matters. If the bar wants lawyers to behave more professionally, it should begin the hard work of adopting and enforcing rules demanding that behavior from them. 